\title{
Cenozoic tectonostratigraphy and pre-glacial erosion: A mass-balance study of the northwestern Barents Sea margin, Norwegian Arctic
}

\author{
Amando Lasabuda a,b*, Jan Sverre Laberg ${ }^{b, a}$, Stig-Morten Knutsen ${ }^{c}$ and Polina Safronova ${ }^{d}$ \\ ${ }^{a}$ Research Centre for Arctic Petroleum Exploration (ARCEx), Department of Geosciences, University \\ of Troms $\varnothing$ - the Arctic University of Norway, NO-9037 Tromsø, Norway \\ ${ }^{\mathrm{b}}$ Department of Geosciences, University of Tromsø - the Arctic University of Norway, NO-9037 \\ Tromsø, Norway \\ ${ }^{\mathrm{c}}$ Norwegian Petroleum Directorate (NPD), Harstad, Norway \\ ${ }^{d}$ ENGIE E\&P Norge, Sandnes, Norway \\ *Corresponding author \\ E-mail addresses: amando.lasabuda@uit.no, ado.amando@gmail.com
}

\begin{abstract}
The evolution of the northwestern Barents Sea continental margin, part of a NW-SE trending mega shear zone, has been reconstructed in order to quantify the sedimentation and erosion affecting this area during and after its formation in the Paleogene-Neogene. This development was closely related to the sea-floor opening of the Norwegian-Greenland Sea. Our study incorporated 2D seismic data, well data, and information from shallow cores.

During the Paleocene-Eocene, the northwesternmost Barents Sea margin was subjected to compression-transpression that led to the development of the West Spitsbergen Fold-Thrust Belt (WSFTB) and largely affected the northern part of the study area. To the south, the Vestbakken volcanic province developed in a pull-apart setting. A transition zone separates these two areas marked by a basin morphology becoming more pronounced to the south suggesting increasing subsidence and extension. Subsequently, during the Oligocene, extension and sea-floor spreading was initiated along the whole margin, resulting in the opening of the Fram Strait between Spitsbergen and NE Greenland in the Miocene.

During the Paleocene, the Stappen High and a part of the NE Greenland shelf sourced sediments into the newly developing basins. The southwestern part of the WSFTB, the Stappen High, and part of the northeastern Greenland margin is interpreted as the main sediment source areas in the Eocene. During the Oligocene and Neogene, a larger part of the northwestern Barents Sea shelf is interpreted to have acted as source area including the Edgeøya platform. As a result of this development, the wider Barents Sea shelf itself is inferred to have been a lowland prior to the northern hemisphere glaciations.
\end{abstract}

We found that the average sedimentation rate for the Paleogene-Neogene at the northwestern Barents Sea margin is about $0.034 \mathrm{~m} / \mathrm{k}$.y. This number is in agreement with the sedimentation 
rate reported from present-day fluvial systems and modern rates coastal erosion. By using a mass-balance approach, we have also estimated the average net erosion and erosion rate for the Paleogene-Neogene period to be $\sim 2440 \mathrm{~m}$ and $0.038 \mathrm{~m} / \mathrm{k} . \mathrm{y}$, respectively. This erosion rate is two times higher compared to the southwestern Barents Sea margin, probably reflecting erosion of a more tectonically active northwestern margin. Thus, for the western Barents Sea margin, a general increasing trend of pre-glacial erosion northwards can be inferred. This study also suggests that more than half of the Cenozoic erosion affecting the studied part of the northwestern Barents Sea was of pre-glacial origin.

Keywords: northwestern Barents Sea, Cenozoic, tectonic, mass-balance, erosion, sedimentation 


\section{Introduction}

The progressive northward onset of sea-floor spreading between mainland Norway and Greenland from the early Cenozoic led to the development of the passive, rift-dominated Norwegian continental margin and the emergence of large, oceanic, deep-sea basins to the west (Faleide et al., 2008; Mosar et al., 2002; Talwani and Eldholm, 1977) (Fig. 1). Further north, along the western Barents Sea - Svalbard continental margin, the tectonic evolution and seafloor spreading was more complex. Here it comprises of an extensional pull-apart basin of the Vestbakken volcanic province, segmented areas of transtension-transpression within the megatransform margin north of the Vestbakken volcanic province (Faleide et al., 1993, 2008), and a major compression-transpression feature: the West Spitsbergen Fold-Thrust Belt (WSFTB) (Bergh et al., 1997; Braathen et al., 1995).

Another key aspect of the Cenozoic evolution of this area is the severe uplift and erosion that has affected the entire Barents Sea shelf and provided much of the sediment now deposited along its western margin (Cavanagh et al., 2006; Henriksen et al., 2011; Laberg et al., 2012; Vorren et al., 2011). This massive denudation has been suggested to have had a strong tectonic and thermal origin in the Paleogene-Neogene (e.g. Vorren et al., 1991; Wood et al., 1989) while a more climatic-glacigenic origin has been suggested during the Pleistocene (e.g. Knies et al., 2009; Laberg et al., 2010).

Integration of new multichannel seismic data and results from shallow cores allows for a more detailed study of the margin segment between Bjørnøya and Svalbard, a presently underexplored part of the Barents Sea margin. The new data has also allowed the separation of siliciclastic basin infilling from nearby land and/or shallow marine areas, sediments deposited from ocean currents (contourites), and glacial sediment input from ice sheets. Moreover, the size of the basin area, the inferred sediment source area, and the sediment pathways can be better constrained by incorporating recent plate reconstruction (Matthews et al., 2016; Müller et al., 2016) to infer the likely paleogeography for the Cenozoic period.

In this paper, we aim to address the pre-glacial Cenozoic basin development in the northwestern Barents Sea, the basin infilling and corresponding erosion of the source area. This is achieved by: 1) establishing a seismic stratigraphic framework and identifying the main tectonic events and phases of basin infill, 2) estimating the sediment volume from the thickness maps for the Paleogene-Neogene deposits along this part of the margin, 3) calculating the average sedimentation rates, and 4) elucidating the sediment source area and estimate average erosion 
rates and sediment flux using the mass-balance technique. From this, we present and discuss our sediment budget, including estimates of average rates of sedimentation in the basins and corresponding erosion of the source area.

\section{Geological setting}

The study area, the northwestern Barents Sea continental margin, is bounded by the Knipovich sea-floor spreading ridge to the west, the Edgeøya platform (Gabrielsen et al., 1990) to the east, Svalbard to the north, and the Vestbakken volcanic province to the south (Fig. 1). The margin was part of the broader Eurekan deformation involving primarily Queen Elizabeth Islands of Canada, north and NE Greenland, and western Svalbard (Piepjohn et al., 2016). The Eurekan Orogeny is believed to be responsible for the major compression structures and major structural lineaments around the Greenland plate boundary (Piepjohn et al., 2016).

The western Barents Sea continental margin has been affected by a series of tectonic events since the early Cenozoic. From the Paleocene-Eocene transition the margin experienced transpression and transtension in a segmented transform setting (De Geer Zone) when the Greenland continental plate moved northwards relative to the Eurasian plate (Faleide et al., 1993, 2008; Steel et al., 1985). The compression-transpression regime formed the current structural configuration of WSFTB (Bergh et al., 1997; Braathen et al., 1995; Leever et al., 2011) shedding sediments to the Central Basin (e.g. Helland-Hansen, 2010). In the Vestbakken volcanic province, a pull-apart basin was initiated in the earliest Eocene with accompanying volcanic activity (Faleide et al., 1988).

In NE Greenland, the NW-SE striking Trolle Land Fault Zone (TLFZ) and the Trolle Land Fault System (TLFS), as part of the Wandel Hav Strike-Slip Mobile Belt, are characterized in the Wandel Sea Basin area (Fig. 1). The basin is identified with numerous Late PaleozoicMesozoic pull-apart basins that were inverted due to the Kronprins Christian Land Orogeny (KCLO) in the Late Cretaceous-early Paleocene (Håkansson and Pedersen, 2001). This is proposed to predate the Eurekan Orogeny (Håkansson and Pedersen, 2015) based on the locally overlying late Paleocene Thyra Ø Formation (Lyck and Stemmerik, 2000). Field mapping from NE Greenland, however, shows a major compression took place in the Paleocene followed by strike-slip movement in the Eocene (Guarnieri, 2015; Svennevig et al., 2016).

Subsequently, the episode of major extension, rifting, and sea-floor spreading occurred when Greenland changed its direction of rotation to the northwest relative to the Eurasian plate in the Oligocene (Lundin and Doré, 2002; Mosar et al., 2002). This extension is suggested to be the 
period of development of the major grabens due to the reactivation of key faults in the northwestern Barents Sea area (Blinova et al., 2009; Gabrielsen et al., 1992). In NE Greenland, the tilt of the Thyra $\varnothing$ Formation and a number of normal faults suggest an extensional phase after the Eurekan Orogeny (Håkansson and Pedersen, 2001).

During the Miocene, the opening of the Fram Strait from this rifting and sea-floor spreading had allowed deep-water circulation between the northeastern Atlantic Ocean and the Arctic Ocean (Engen et al., 2008; Jakobsson et al., 2007; Jokat et al., 2016; Kristoffersen, 1990) and marked the onset of contouritic sedimentation along the northwestern Barents Sea margin (Eiken and Hinz, 1993; Gebhardt et al., 2014). Subsequently, the Pleistocene was a period of extensive glaciations with ice-sheets repeatedly covering the Barents Sea shelf and Svalbard (Knies et al., 2009; Vorren et al., 2011). The trough-mouth fans (TMF's) along the western margin are characterized by a considerable amount of glacigenic sediments as a product of glacial erosion largely from the shelf areas to the east during this period (Dahlgren et al., 2005; Fiedler and Faleide, 1996; Laberg and Vorren, 1996; Solheim et al., 1998).

\subsection{Structural elements}

In the study area, the main structural elements formed and/or reactivated during the Cenozoic including the Hornsund Fault Zone, the Knølegga Fault, and the Stappen High (Fig. 2) as further detailed below.

The Hornsund Fault Zone (HFZ) (Bergh et al., 1997; Bergh and Grogan, 2003; Faleide et al., 2015; Gabrielsen et al., 1997) or 'Hornsund fault complex' (Gabrielsen et al., 1990) consists of a set of presently normal faults that typically show a NW striking trend in the northern part of the study area and gradually become N-S trending towards the south (Fig. 2b) (Gabrielsen et al., 1990). This fault zone is interpreted to have been active as predominantly dextral strike-slip faults with traces of reverse faults during the northward movement of Greenland in the early Cenozoic. The change of Greenland's pole of rotation also affected this fault zone to be dominated by extension, which was concurrent with the onset of sea-floor spreading west of Svalbard during the early Oligocene (Faleide et al. 2008).

The Knølegga Fault $(K F)$ is an overall N-S striking normal fault that is located west of the Stappen High extending southwards to the Vestbakken volcanic province (Fig. 2b). This fault appears as an extensional fault throughout the Cenozoic, since the initial opening of this part of the Norwegian-Greenland Sea. This fault has been given a formal status by NPD (Gabrielsen et al., 1990) and named as the Knølegga Fault. Some publications, however, have been using 
the name Knølegga Fault Complex or Knølegga Fault Zone (e.g. Faleide et al., 1993; Sættem et al., 1994).

The Stappen High is located in the southern part of the studied area with Bjørnøya appearing as the subaerial part of the high (Fig. 2b). Triassic to Devonian rocks are subcropping at the Stappen High and younger strata are largely missing indicating that it has been affected by episodes of uplift and erosion (Dallmann, 2015; Worsley et al., 2001). Uplift and erosion has been documented for the Cenozoic period as the Stappen High appears as the main source of sediment for the middle Eocene submarine fan complex in the Sørvestsnaget Basin to the south (Safronova et al., 2012; 2014).

\subsection{Continental-Ocean Boundary}

To the west, the oceanic crust shows an irregular morphology with a series of minor normal faults (e.g. Fig. 4). The oceanic crust is often defined by a strong magnetic anomaly due to its higher density and magnetic susceptibility. In magnetic maps, its development is commonly parallel to the sea-floor spreading axis, which makes it relatively easy to identify. However, in the study area, the lack of a regular pattern indicates complex sea-floor spreading (e.g. Mosar et al., 2002; Olesen et al., 2010) as well as an intricate relationship with the nature of the Knipovich Ridge to the west (e.g. Gusev and Shkarubo, 2001). The precise location of the continental-oceanic boundary $(\mathrm{COB})$ is dependent on the resolution and quality of the available data. The oceanic crust was formed during the progressive sea floor opening, probably since the earliest Eocene, followed by Oligocene sea-floor spreading due to plate reorganization (Talwani and Eldholm, 1977). This configuration allows the Knipovich Ridge to form in the earliest Oligocene time and is suggested as a segmented slow spreading ridge (Sokolov et al., 2014; Zarayskaya, 2017).

\subsection{Uplift and Erosion}

The Barents Sea shelf has undergone an extensive denudation during the Cenozoic. A total average (net) denudation of up to ca. $3 \mathrm{~km}$ has been estimated in the northwestern Barents Sea and on Svalbard (Henriksen et al., 2011; Riis and Fjeldskaar, 1992). The major period of erosion has previously been interpreted to have occurred during the late Cenozoic as a result of glacial erosion evident from the TMF development (Faleide et al., 1996; Hjelstuen et al., 1996; Laberg et al., 2010; Laberg et al., 2012; Vorren et al., 1991). However, early to middle Cenozoic (preglacial) denudation also occurred in this area (see Cavanagh et al., 2006 for a review). A considerable amount of pre-glacial sediments are seen overlying the oceanic crust underneath 
the Storfjorden TMF, which is dominated by glacigenic sediments of Pleistocene age (Hjelstuen et al., 1996).

It has been suggested that regional exhumation episodes during the Paleogene-Neogene have affected the broader north Atlantic region including the study area. This is based on results from apatite fission track (AFT) data (Green and Duddy, 2010) and other methods (see review by Anell et al., 2009). Two main periods of Cenozoic pre-glacial uplift, 65-40 Ma and 40-20 Ma, are inferred from wells in the southwestern Barents Sea using AFT (Hendriks, 2017). Lasabuda et al. (in review) estimated that $850-1360 \mathrm{~m}$ of erosion has affected the southwestern Barents Sea area (the area south of Bjørnøya) during the Paleogene-Neogene. To the north, the Upper Cretaceous succession is absent on Svalbard suggesting major erosion and/or non-deposition during or after this period. These observations imply that the pre-glacial component may be responsible for a significant contribution to the total average net erosion in the northwestern Barents Sea, but this is still poorly constrained.

\section{Data and methods}

This study has been carried out by interpreting a set of 2D seismic lines, provided by the Russian Joint Stock Company ‘Marine Arctic Geological Expedition' (MAGE), collected in 2002-2006 (Fig. 2a). The main 2D seismic survey covers an area of ca. 41,000 km². Assuming a dominant frequency $(f)$ of $30 \mathrm{~Hz}$ and a seismic P-wave velocity $(v)$ of $\sim 2300 \mathrm{~m} / \mathrm{s}$ reported at $1000 \mathrm{~m}$ depth in Pleistocene strata at Ocean Drilling Site (ODP) Site 986 (Jansen et al., 1996), the average vertical resolution has been calculated to ca. $20 \mathrm{~m}$ (v/4f) (e.g. Safronova et al., 2015). Assuming a lower dominant frequency of $15 \mathrm{~Hz}$ due to more pronounced seismic attenuation, the vertical seismic resolution is reduced to ca. $70 \mathrm{~m}$ considering an average P-wave velocity of $\sim 4420 \mathrm{~m} / \mathrm{s}$ from well $7316 / 5-1$ at depth $3800-4000 \mathrm{~m}$ of upper Paleocene interval. Taken together, this gives a vertical resolution in a range of 20-70 $\mathrm{m}$ for the targeted interval. The 2D seismic data has a generally good quality although there are some noises related to shallowwater seabed multiples especially on the shelf. A seismic stratigraphic analysis, as outlined by Mitchum and Vail (1977), has been applied to define the boundary reflections, and the external and internal seismic geometry of each of the seismic units. The fault interpretation of this study also utilizes the results of Bergh and Grogan (2003) and Faleide et al. (2015).

In addition, exploration well data and information from shallow cores have been integrated (Fig. 2a). The only exploration well close to the study area is well 7316/5-1 in the Vestbakken volcanic province. This well has been used to tie the seismic horizons and to provide age control 
(Eidvin et al., 1998; 2013). To the northwest of the study area, ODP Site 986 (Jansen et al., 1996) is used to tie the base of the glacigenic sediments (surface R7 of Faleide et al., 1996). Information from DSDP Site 344 (Talwani and Udintsev, 1976) has also been added to guide mapping of the sediment distribution near the axis of the spreading ridge. This study has also benefited from sedimentological information and chronology from the shallow cores 7418/01U-01 and 7517/12-U-01 (Eikelmann, 2017; Grogan et al., 1999). In addition, the PaleogeneNeogene strata are seen to systematically overlie the oceanic crust westwards (Figs. 4 and 5), contemporaneous with the sea-floor spreading (e.g. Fiedler and Faleide, 1996). This observation has been used to estimate the maximum age of the sediments here.

The time-to-depth conversion of the seismic data was carried out using the velocity gradient of Hjelstuen et al. (1996). This relationship was used to convert the isopachs to estimate the sediment volumes. The volume of each seismic unit was then used to calculate the average (linear) sedimentation rates. The size of the Cenozoic basin for each area is based on plate reconstructions using GPlates v. 2.0 (Matthews et al., 2016; Müller et al., 2016). In the massbalance technique, the depositional volume is used to estimate the erosional volume following some assumptions and corrections (Fig. 3). The primary idea of this method is to relate the deposited sediments to their interpreted source area and then estimate the net erosion, erosion rate, and sediment yield (Fig. 3). This approach is identical to the source-to-sink method (e.g. Sømme et al., 2009). Source-to-sink studies addressing pre-glacial Cenozoic or even older systems (Jurassic and Triassic) show that the offshore sedimentary records can be linked to modern systems (Eide et al., 2017; Sømme et al., 2013). Assumptions have also been made relating to the nature of the bedrock lithology of the drainage area, the compaction of the deposited sediments, and the sedimentation/erosion processes involved (Fig. 3).

Sediment discharge was obtained by using density of $2.2 \mathrm{gr} / \mathrm{cm}^{3}$ following Lasabuda et al. (in review) that have calculated the average density for Paleogene-Neogene strata from wells in the southwestern Barents Sea. By combining the sediment discharge and drainage basin area, the sediment yield was also obtained. The average net erosion of the source area was estimated from the erosional volume divided by the size of the source area. The average erosion rate was then obtained for each of the studied periods (Fig. 3).

For the source area, we focus on processes of sediment erosion, denudation is not considered. Erosion is the surface processes of sediment removal, in contrast to denudation that may include both surface and subsurface processes (i.e. loss of mass through chemical dissolution), the latter not always accompanied by erosion (Doré et al., 2002). Denudation is defined as erosion within 
a thermal frame of reference and often measured from vitrinite reflectance and AFT (Riis and Jensen, 1992). In our mass-balance approach, the erosional volume is estimated from what has been deposited in the basin area (depositional volume) through clastic sediment transport processes (Fig. 3). Thus, we do not account for any loss of mass due to chemical dissolution as well as any gain of mass due to biological or chemical process (e.g. ooze sediments) (Fig. 3), both considered to be of minor importance for the area and time period considered.

\section{Results}

\subsection{Area subdivision and structural style}

The study area has been subdivided into three main segments: the western, the central, and the eastern segment based on their structural style, in accordance with Bergh and Grogan (2003) (Fig. 2b). The eastern segment is characterized by the structurally less complex Edgeøya platform and the elongated, north-south oriented, Stappen High. The eastern segment consist of continental crust (Faleide et al., 2015). The central segment is bounded by two major fault zones, part of the Hornsund Fault Zone to the west and the inferred offshore prolongation of the Billefjorden Fault Zone to the east. Further south, the eastern margin of the central segment is delimited by the Knølega Fault that separates this area and the Stappen High to the east (Fig. 2b). The central segment is dominated by a series of highs and basins that mimic the structural configuration found on Spitsbergen (Bergh and Grogan, 2003). From seismic mapping, this central segment shows a narrowing trend northwards (Figs. 4-7). The central segment is located in a transition zone of continental and oceanic crust (Faleide et al., 2015). The western segment comprises mainly oceanic crust underlying Paleogene-Neogene sediments and the Pleistocene Storfjorden TMF (Hjelstuen et al., 1996).

The study area is characterized by two different faults (Bergh and Grogan, 2003). The first set, the Hornsund Fault Zone and the Knølegga Fault, consists of deep-seated and probably basement-involved faults. These major faults have likely played a key role in the tectonic development in the study area. The second set of faults are interpreted as smaller faults that have displaced Cenozoic strata. This fault classification is also identical with what has been proposed by Gabrielsen (1984) who named them first and second class faults. Therefore, in this study, the Hornsund Fault Zone and the Knølegga Fault are classified as the major fault sets and the other smaller fault sets are the minor faults mainly occurring in the central segment (Fig. 2b). 
The normal faults appear to dominate the area to the south of Bjørnøya, suggesting the dominance of extension in the Vestbakken volcanic province (Fig. 4). A set of high-amplitude reflections is interpreted to be volcanics, which appeared in the lower Eocene unit in the Vestbakken volcanic province (Fig. 4). These volcanics are associated with the sea-floor spreading in the earliest Eocene (Faleide et al., 2008)

North of Bjørnøya to $75^{\circ} 50 \mathrm{~N}$, the central segment appears to be highly influenced by strikeslip and normal faulting (Fig. 2b). Rollover structures are observed with the potential for detachment surfaces to accommodate the listric normal fault movement (Fig. 5). A series of antithetic faults is also observed along with horst and graben structures (Fig. 6). The Knølegga Fault is seen separating a N-S trending mini-basin with the Stappen High (e.g. Fig. 6.

Further to the north, seismic profiles show a complex structural development (Fig. 7). A set of normal faults is observed forming horst and graben structures (Fig. 8). The structural style in the central segment also shows negative flower structures suggesting the significance of transtension in this part of the segment. The apparent thickening of the lower Eocene strata in the hanging wall of the normal faults indicate that fault development occurred at this time (Figs. 6 and 8). Some of the faults are offsetting the lower-middle Eocene to Neogene strata that suggests a period of extension sometime prior to the development of the Pleistocene glacial wedge (Figs. 6 and 8).

Between $75^{\circ} 50 \mathrm{~N}$ and the WSFTB, the seismic data is highly affected by multiples, masking the structural elements in the central segments (Fig. 9). Therefore, the fault interpretation here is mostly according to Bergh and Grogan (2003). In the eastern segment, a distinct truncation of the strata is seen from the seismic profiles and the subcropping of the Cretaceous strata flanking a younger (Cenozoic) core (Grogan et al., 1999) (Fig. 9). To the west, hints of a downlapping reflection pattern onto the oceanic crust suggests that the Cenozoic strata was largely sourced from the east (Fig. 9).

\subsection{Seismic stratigraphy}

Five seismic units have been identified in the study area based on their age (tied to commercial and scientific well data) and their seismic signature. These units show lateral variations in terms of thickness and distribution as well as internal seismic reflection pattern. The depositional environment for each unit will be discussed below. 


\subsubsection{The Paleocene unit}

The Paleocene unit is bounded below by the base Paleocene reflection and above by the base lower Eocene reflection. The base Paleocene is generally defined by a high amplitude, relatively continuous or irregular reflection on the seismic data (Fig. 6). To the west, this unit is observed having a sharp contact with the later developed oceanic crust (e.g. Fig. 7). The base Paleocene marks the base of the Cenozoic sediments and displays an unconformable contact with the underlying strata (Fig. 6).

The Paleocene unit is dominated by high-amplitude internal reflections with moderate continuity (Fig. 8). This unit shows a general thinning northeastwards (Fig. 10a) and a distinct displacement of this unit is seen at the fault marking the western boundary of the central segment (e.g. Fig. 7). The Paleocene unit has a limited distribution westwards due to the position of Greenland during the Paleocene (Fig. 10a). Within the eastern segment, the unit is absent as it is truncated by the overlying R7 surface (base of the glacigenic deposits) or the seafloor surface (Figs. 7 and 9). The R7 surface represents a basal erosion surface due to icesheet development on the shelf and glacigenic mass-wasting processes on the continental slope (Laberg et al., 2010).

In shallow core 7517/12-U-01, located within the central segment, a late Paleocene age interval is reported and interpreted as shoreface deposits (Eikelmann, 2017). Shallow core 7418/01-U01 also within the central segment shows shale-dominated deposits of late Paleocene-early Eocene age, interpreted to represent deposits in a more deep-marine environment (Eikelmann, 2017). Thus, a transition from a shallow shelf to a deep-marine paleo-geography is suggested for the Paleocene unit in the central segment.

\subsubsection{The lower Eocene unit}

The base of the lower Eocene unit shows a high-amplitude and relatively continuous reflection (Fig. 6). The internal geometry of this unit is characterized by a series of semi-continuous, parallel reflections of lower amplitude compared to the underlying Paleocene unit (e.g. Fig. 8). Seismic data shows an increase in thickness suggesting fault growth during this period (Figs. 6 and 8). To the east, this unit is onlapping the Stappen High and truncated by the R7 surface (Fig. 6). In the western segment, this unit is partly onlapping oceanic crust (Fig. 5). The isopach thickness map for this unit is combined with the middle-upper Eocene unit, which is described in the following sub-chapter. 
Shallow core 7418/01-U-01 contains lower Eocene sediments while these deposit are absent in core 7517/12-U-01 (Eikelmann, 2017). In shallow core 7418/01-U-01, lower Eocene strata occur as mud-dominated rocks with traces of bioturbation. The texture and sediment structures indicate that these sediments were deposited in a deep-marine environment (Eikelmann, 2017).

\subsubsection{The middle-upper Eocene unit}

The base of the middle-late Eocene unit is characterized by relatively continuous reflection with low to medium amplitudes (Fig. 6). Within the central and eastern segments, this unit is directly overlain and truncated to the east by the R7 surface (e.g. Fig. 5). The internal geometry includes semi-parallel reflections of primarily low amplitude (e.g. Fig. 6). In the western segment, this unit is observed conformably overlying the oceanic crust and onlapping the irregular morphology of the crust (e.g. Fig. 5).

A pronounced thickening of this unit is interpreted within the Hornsund Fault Zone, particularly in the northern part of the central segment (Fig. 9). Northeastwards, towards Svalbard, the Eocene unit is significantly thinning and finally absent (Fig. 10b). The combined Eocene isopach map displays a prominent thickness of this unit towards the south exceeding $4 \mathrm{~km}$ in the Vestbakken volcanic province (Fig. 10b). To the west, this unit has a wider extent compared to the underlying Paleocene unit in line with the contemporaneous sea-floor opening (Figs. 10a and b). This unit is absent in core 7517/12-U-01 but present in core 7418/01-U-01, where it is described as middle Eocene strata (Eikelmann, 2017). The unit was reported as predominantly mudstone and interpreted as being deposited in a slope/basin floor paleoenvironment (Eikelmann, 2017).

\subsubsection{The Oligocene unit}

The base of the Oligocene unit is defined by an overall low to medium amplitude reflection (e.g. Fig. 6). The internal geometry shows reflections with highly variable seismic amplitudes and predominantly sub-parallel reflections (e.g. Fig. 8). The lateral extent of the Oligocene unit is limited to the western segment as this unit is truncated to the east towards the Hornsund Fault Zone by the R7 surface (Fig. 10c). The Oligocene unit is also observed onlapping the oceanic crust to the west (Fig. 9).

The Oligocene unit displays a uniform thickness across the study area except in the western part of the western segment (Fig. 10c). Here, a thickness of up to $2400 \mathrm{~m}$ is observed within a crustal depression. In the southern part of the central segment, this unit is present and directly 
overlain by glacigenic sediments (Fig. 4). There are no Oligocene sediments within the shallow cores in the study area (Eikelmann, 2017; Grogan et al., 1999). However, the closest well to the south (7316/5-1) shows Oligocene strata interpreted to be shallow-marine sediments (Eidvin et al., 1998; 2013; 2014).

\subsubsection{The Neogene unit}

The base of the Neogene unit is defined by a moderate amplitude and semi-continuous reflection showing a conformable contact to the underlying deposits (Fig. 8). The Neogene unit is defined by the $\mathrm{R} 7$ surface above. The $\mathrm{R} 7$ reflection shows a medium to high amplitude and is relatively continuous throughout the study area, representing a regional erosional unconformity (e.g. Fig. 6). The internal seismic signature of the Neogene unit is dominated by sub-parallel internal reflections (Fig. 8). A set of imbricated, continuous seismic reflections is observed onlapping towards the Hornsund Fault Zone (Fig. 5, see inset). These deposits are interpreted as contouritic sediments that have been deposited from ocean currents.

The isopach map shows a thickening trend to the west where a maximum sediment thickness of up to $2 \mathrm{~km}$ occurred locally in the depocenter (Fig. 10d). Similar to the underlying Oligocene unit, the Neogene unit is also absent in all of the shallow cores within the study area (Eikelmann, 2017; Grogan et al., 1999). The Neogene strata is, however, also present in well 7316/5-1, and is here documented to be of lower Miocene age (Eidvin et al., 1998; 2013; 2014). To the north, the initial report of site ODP 986 shows recovered Miocene sediment (Jansen et al., 1996), but a later revision found that Miocene sediments were not deposited at this site (Channell et al., 1999; Eidvin and Nagy, 1999; Smelror, 1999). In addition, DSDP site 344 located immediately east of the Knipovich Ridge has been found to contain Miocene or lower Pliocene sediment (Talwani and Udintsev, 1976). Therefore, we include the sediments within the area of DSDP Site 344 in our pre-glacial sediment budget (Fig. 10d).

\subsection{Sediment volume, sedimentation rates, and depositional area}

From the isopach maps, the sediment volume for each of the seismic units and the total volume have been calculated (Table 1). The total corrected sediment volume for the PaleogeneNeogene is estimated to be about $115,400 \mathrm{~km}^{3}$. There is a substantial increase in sediment volume from the Paleocene to the Neogene, from $\sim 8,900$ to $51,200 \mathrm{~km}^{3}$ (Table 1). The total volume here is regarded as a minimum volume due to limited seismic coverage in the western segment. 
The sedimentation rates are estimated from the corrected sediment volume (Fig. 3). For the Neogene unit, the sedimentation rate has also been estimated to exclude contouritic deposits (see below). Our calculations show that the sedimentation rate increased from the Paleocene to the Oligocene, from $0.059 \mathrm{~m} / \mathrm{k}$.y. to $0.089 \mathrm{~m} / \mathrm{k} . \mathrm{y}$. to drop to $0.047 \mathrm{~m} / \mathrm{k} . \mathrm{y}$. for the Neogene (Table 1). For the Paleogene-Neogene periods the total average sedimentary rate is estimated to be $\sim 0.34 \mathrm{~m} / \mathrm{k} . \mathrm{y}$. when assuming a uniform depositional area of $53,200 \mathrm{~km}^{2}$ for the whole period. The interpreted depositional area was smallest during the Paleocene and Eocene periods, 15,100 and $16,200 \mathrm{~km}^{2}$, respectively, to increase during the Oligocene and Neogene as sea-floor spreading commenced (Table 1; Fig. 10).

\begin{tabular}{ccccc}
\hline $\begin{array}{c}\text { Periods considered } \\
(\mathrm{Ma})\end{array}$ & $\begin{array}{c}\text { Sediment volume } \\
\text { from isopach } \\
\text { maps } \\
\left(10^{3} \mathrm{~km}^{3}\right)\end{array}$ & $\begin{array}{c}\text { Corrected } \\
\text { sediment volume } \\
\left(10^{3} \mathrm{~km}^{3}\right)\end{array}$ & $\begin{array}{c}\text { Depositional } \\
\text { area }\left(10^{3} \mathrm{~km}^{2}\right)\end{array}$ & $\begin{array}{c}\text { Sedimentation } \\
\text { rates }(\mathrm{m} / \mathrm{k} . \mathrm{y})\end{array}$ \\
\hline Neogene $(23.03-2.58)$ & 54.2 & 51.2 & 53.2 & 0.047 \\
Oligocene (33.9-23.03) & 29.6 & 31.1 & 35 & 0.082 \\
Eocene $(56-33.9)$ & 23.1 & 24.4 & 16.2 & 0.067 \\
Paleocene $(66-56)$ & 8.4 & 8.9 & 15.1 & 0.059 \\
Paleogene - Neogene (66-2.58) & 115.3 & 115.4 & 53.2 & 0.034 \\
\hline
\end{tabular}

Table 1. The corrected sediment volumes are estimated after corrections due to sediment deposition and decompaction have been applied. The sedimentation rates are estimated from the corrected sediment volumes. The corresponding sedimentation rates show a gradual increase from the Paleocene to the Oligocene before it drops during the Neogene. Time scale is according to Cohen et al. (2016).

\subsection{Average net erosion, erosion rates of drainage area and sediment yield}

The volumetric mass-balance approach (e.g. Vorren et al. 1991; Faleide et al., 1996; Laberg et al. 2012) is then used in order to estimate the amount of erosion of the source area. Below are assumptions and corrections applied before converting the depositional volume to the erosional volume (Fig. 3). The drainage area for the Paleogene-Neogene period is primarily interpreted to be the southwestern Svalbard area, the northwestern Barents Sea shelf, and part of northeastern Greenland and was dominated by clastic sediment transport processes and deposits (Fig. 10). Some of the isopached sediments were not derived from the source area (e.g. contourites) and must therefore be excluded from our estimates. Part of the Neogene sediments 
are contourites that were deposited from ocean currents and most likely derived from the continental margin south of the study area. To compensate this, the sediment volume was reduced by $10 \%$. This correction is according to Stow et al. (2008) which quantifies the interaction between the turbiditic currents, bottom-currents influx, and pelagic settling in forming sediment drifts and suggest 8-14\% from the total drift deposits were transported from neighboring slope area by contour currents.

Part of the Paleogene strata documented from wells 7216/11-1S and 7316/5-1 are of biogenic ooze origin (deposits produced within the basin). It is presently not known whether similar deposits also occur in the northwestern Barents Sea. Therefore, our sediment volume will not be corrected for ooze sediments. It is noteworthy that due to later glacial erosion, a substantial part of the Paleogene-Neogene deposits have been eroded to the east. Much of these sediments formed the TMFs in the late Cenozoic.

A sediment decompaction correction was also applied to compensate the compaction of the Paleogene-Neogene deposits by the overburden glacigenic sediment. We used a decompaction value of 5\% following Lasabuda et al. (in review) based on a diagram of vertical effective stress (Bjørlykke and Høeg, 1997). Furthermore, assuming that most of our source areas were composed of sedimentary rocks (Piepjohn et al., 2016; Smelror et al., 2009), a correction due to a significant difference in bedrock composition between our source area and the studied deposits were not considered (e.g. Dowdeswell et al., 2010).

\begin{tabular}{ccccccc}
\hline $\begin{array}{c}\text { Periods considered } \\
(\mathrm{Ma})\end{array}$ & $\begin{array}{c}\text { Volume of } \\
\text { the source } \\
\text { area }\left(10^{3} \mathrm{~km}^{3}\right)\end{array}$ & $\begin{array}{c}\text { Sediment } \\
\text { discharge } \\
\left(10^{6} \mathrm{t} / \mathrm{y}\right)^{*}\end{array}$ & $\begin{array}{c}\text { Drainage } \\
\text { area } \\
\left(10^{3} \mathrm{~km}^{2}\right)\end{array}$ & $\begin{array}{c}\text { Sediment } \\
\text { yield } \\
\left(\mathrm{t} / \mathrm{km}^{2} / \mathrm{y}\right)\end{array}$ & $\begin{array}{c}\text { Erosion } \\
(\mathrm{m})\end{array}$ & $\begin{array}{c}\text { Erosion } \\
\text { rates } \\
(\mathrm{m} / \mathrm{k} . \mathrm{y})\end{array}$ \\
\hline Neogene $(23.03-2.58)$ & 51.2 & 5.5 & 78.2 & 70.5 & 655 & 0.032 \\
Oligocene $(33.9-23.03)$ & 31.1 & 6.3 & 78.2 & 80.4 & 397 & 0.037 \\
Eocene (56-33.9) & 24.2 & 2.4 & 28 & 86.1 & 865 & 0.039 \\
Paleocene (66-56) & 8.9 & 2 & 17 & 114.8 & 522 & 0.052 \\
Paleogene-Neogene & 115.4 & 4 & 78.2 & 51.2 & 2439 & 0.038 \\
$(66-2.58)$ & & & & & & \\
\hline
\end{tabular}

*density $2.2 \mathrm{gr} / \mathrm{cm}^{3}$

Table 2. Erosion volumes derived from the depositional volumes using the mass-balance approach. Sediment discharge and drainage area reflects the amount of sediments draining from the source area per year. These numbers will later be compared with present-day systems. Average erosion and erosion rate are also shown. 
From this, the erosional volume is estimated to be $115,400 \mathrm{~km}^{3}$ (Table 2). The total average erosion for the Cenozoic's pre-glacial strata is thus estimated to be up to $\sim 2440 \mathrm{~m}$ with an erosion rate of $0.038 \mathrm{~m} / \mathrm{k} . \mathrm{y}$. The period of highest average erosion was during the Eocene characterized by ca. $865 \mathrm{~m}$ of erosion.

\subsection{Uncertainties of the approach and their constraints}

There are uncertainties related to the seismic interpretation, including the age of the sediments around the $\mathrm{COB}$, and the delineation of the source and basin area. In addition, due to the limited seismic coverage to the west, uncertainty also lies on the sediment volume in the westernmost part of the study area (close to the Knipovich Ridge), where a rougher topography in the oceanic crust domain is present, making detailed mapping challenging. Refinement here must await an expanded seismic data base.

This study strongly relies on lithological information available in wells (1998; e.g. Eidvin et al., 1993; 2013; 2014) and is expanded upon using seismic data. The highest uncertainty relates to the seismic interpretation of the Oligocene and Neogene strata, due to few tie points to the seismic data and the limited distribution of the sediments on the shelf (e.g. Ryseth et al., 2003).

Uncertainty related to COB-sediment correlation and the age of the oceanic crust may be higher in the study area compared to areas of well-defined magnetic anomalies, e.g. mid-Norway. In addition, the source area delineation is sensitive in the mass-balance approach. Our approach includes also carefully considering the paleotopography of the source area (see below) as well as the size of the source area to the south (Lasabuda et al., in review). Another uncertainty is related to the size of the source and basin area. Previous work on the same area assumed a constant size of the source and basin throughout the entire Cenozoic period (Hjelstuen et al., 1996). However, this seems unlikely owing to contemporaneous plate movement and subsequent development of an oceanic basin to the west. In this study, we address these issues by using a plate reconstruction to better constrain the size of the Cenozoic source and basin for each periods.

The plate reconstruction was created with open source GPlates software v. 2.0, which is an improved version from the previous plate kinematic model (Seton et al., 2012). In particular, the updates have been in the area of the plate rotation model (Matthews et al., 2016), the oceanic paleo-age grid model (Müller et al., 2016), and the net lithosphere rotation (Torsvik et al., 2010). This software also implements the NE Atlantic plate kinematic model by Gaina et al. (2009), which also has been used by Faleide et al. (2015). A recent application of GPlates v. 
2.0 addressing the Eurekan Orogeny (Gion et al., 2017) fits well with results from field mapping (Piepjohn et al., 2016), suggesting that this software is reliable.

\section{Discussion}

\subsection{Early to middle Cenozoic development of the northwestern Barents Sea continental margin and surrounding land areas}

A complex tectonic development of the northwestern Barents Sea continental margin occurred as a response to the early Cenozoic break up and subsequent movement of the Greenland plate relative to Eurasia (Talwani and Eldholm, 1977; Faleide et al., 2008). This led to the development and/or modification of marginal highs along the northwestern Barents Sea, which later subjected to erosion.

The area north of Bjørnøya, the central segment, appears to be dominated by extension as is evident from a series of normal faults and rollover structures (Fig. 6). The listric normal faults may have been detached to evaporites as a decollement surface. The evaporites may have been originated from the Permian strata, as also found on Svalbard (Dallmann, 2015).

The area south of $75^{\circ} 50 \mathrm{~N}$ is likely to have been highly affected by strike-slip faulting. The negative flower structure suggests a major transtension development in the early Eocene (Fig. 8). This dextral strike-slip fault can be attributed to the broad transform zone owing to the northwards movement of Greenland relative to the Barents Sea shelf (Faleide et al., 1993).

Based on the structural style, the area north of $75^{\circ} 50 \mathrm{~N}$ is suggested as the offshore continuation of the WSFTB (Bergh and Grogan, 2003). The early Cenozoic tectonics that caused the WSFTB further east may have been affected by the Hornsund Fault Zone. A basement-involved horst has been interpreted to be formed during the major tectonic compression-transpression in this period (Bergh and Grogan, 2003).

The characteristics of the two major faults are summarized in Figure 11. The Hornsund Fault Zone appears as a compressional-transpressional fault during the Paleocene-Eocene transition and subsequently acted as a normal fault in the Oligocene (Bergh and Grogan, 2003). In contrast, the Knølegga Fault appears to be a normal fault since the early Cenozoic (e.g. Gabrielsen et al., 1990). This direction of movement was amplified by the renewed uplift of the adjacent Stappen High to the east in the early Cenozoic (Sættem et al., 1994).

From seismic mapping, the pre-glacial erosional products are largely found in the central and western segment above the emerging oceanic crust. Some of these sediments were later eroded 
and transported westwards during late Cenozoic glaciations forming the Storfjorden TMF (Hjelstuen et al., 1996). Below, we link the offshore sediment volume to the most likely sediment source area. The size of the source areas and its delineation will be evaluated, taking the plate configuration for each period into consideration. In addition, the corresponding erosion estimates will be discussed and related to the regional development of the area. Clastic sediments are interpreted to have dominated the source area during the Paleogene-Neogene period.

\subsubsection{Paleocene paleoenvironment and erosion of the source area}

The Paleocene strata shows a relatively uniform sediment distribution across the study area with a slightly thinning northward trend (Fig. 10a). This is consistent with results from well 7316/5-1 and shallow cores 7517/12-U-1 and 7418/1-U-1 indicating a basin deepening towards the south (1998; Eidvin et al., 1993; Eikelmann, 2017). Lack of sediments to the east is probably due to later glacial erosion. The Stappen High may have extended further north and appears as the key sediment source area at this time, based on the sediment distribution (Fig. 12a). Plate reconstructions shows that northeastern Greenland was located considerably closer to the Stappen High during the Paleocene (Fig. 10a). This implies that sediment input to the Paleocene basin from northeast Greenland is very likely. Therefore, we tentatively infer a source area on the northeast Greenland margin of similar size to the Stappen High (Fig. 12a).

It has been suggested that the Stappen High may already have been an individual block forming a positive bathymetry prior to the Cenozoic (e.g. Grundvåg and Olaussen, 2017). Gernigon and Brönner (2012) documented this high as an independent Precambrian block similar to the Loppa High, also supported by Olesen et al. (2010). During the Paleocene, the Stappen High was subjected to erosion, shedding sediment to the adjacent basins (e.g. Lasabuda et al., in review). The volume of the eroded sediments $\left(\sim 8,900 \mathrm{~km}^{3}\right)$ is the lowest in comparison to the volume of sediments deposited in the subsequent periods (Table 2). This relatively small volume represents the condition prior to the major Cenozoic tectonic activity along the western Barents Sea margin. However, studies of the NE Greenland paleo-stress indicated that this area and the northwest Barents Sea was subjected to compression in the Paleocene (Guarnieri, 2015). Compression at this period, affecting the Trolle Land Fault Zone, is also suggested from combined seismic data and magnetic anomaly (Døssing et al., 2010). The inverted pull-apart basins, due to the Kronprins Christian Land Orogeny, formed a domal folding structure (Håkansson and Pedersen, 2001), probably emerged as a source of sediments for the adjacent basins (Fig. 10a). Thus, NE Greenland and the Stappen High probably represented a 
topographic high during the Paleocene, separated by an abrupt transition to the deep rift basin (Fig. 12a).

A sediment discharge of $2 \times 10^{6} \mathrm{t} / \mathrm{y}$ from a source area of $\sim 17,000 \mathrm{~km}^{2}$ is comparable with results from present-day mountainous areas in the High Arctic (Fig. 14). The average erosion occurring during this period is estimated to be $\sim 522 \mathrm{~m}$ with an average erosion rate of 0.052 $\mathrm{m} / \mathrm{k}$.y. Basin modelling study from NE Greenland shows erosion of up to $300 \mathrm{~m}$ in the Paleocene interval (Stemmerik et al., 1998), which shows a conformity with our numbers.

\subsubsection{Eocene paleoenvironment and erosion of the source area}

Eocene strata thins and ultimately disappears to the northeast probably due to the late Cenozoic glacial erosion (Fig. 10b). In addition, a distinct thickness increase of up to $4 \mathrm{~km}$ is observed to the south and west of Bjørnøya as part of the Vestbakken volcanic province development (Fig. 10b). Further west, basin widening and deepening occurred as a result of the contemporaneous sea-floor opening. Here, offshore shale (Eikelmann, 2017) and sandy submarine fans (1998; Eidvin et al., 1993) dominated the Eocene interval. The sediments are interpreted to be sourced primarily from the Stappen High (Fig. 12b). However, plate reconstruction shows that Greenland may still be relatively close to the NW Barents Sea area (Fig. 10b). The major Eocene event is interpreted to amplify the topographic high in NE Greenland and acted as sediment source area for the developing ocean basin (Fig. 12b). This transform activity affecting the Wandel Hav Strike Slip Belt (Piepjohn et al., 2016) was also recorded from fault mapping onshore NE Greenland (Svennevig et al., 2016). Moreover, a considerable amount of Eocene sediment has been deposited in Danmarkshaven Basin, which was sourced from Greenland (Petersen et al., 2015). This shows Greenland as an important source area to the adjacent basins during the Eocene.

The Stappen High might have been part of a continuous subaerial topography towards Svalbard in the Eocene, separating a deeper marine area to the west from a shallower marine paleoenvironment of the Edgeøya platform area to the east (Fig. 13). According to this scenario, this positive topography may represent part of the fold-thrust belt on Svalbard, formed in response to the massive compression-transpression primarily during the Eocene (Bergh et al., 1997). Moreover, an episode of uplift is inferred to have affected the Stappen High during this period (Sættem et al., 1994; Wood et al., 1989). Therefore, it is reasonable to assume that the high extended towards Svalbard (Dallmann, 2015; Smelror et al., 2009). The Eocene clinoforms identified in the Central Basin (Steel et al., 1985; Helland-Hansen, 2010) may have continued 
southwards but they are difficult to trace due to later erosion. However, the Stappen High was shedding sediments towards the Sørvestsnaget Basin to the south where submarine fans were deposited (Safronova et al., 2012; 2014). The combined source area of NE Greenland and the Stappen High covered $28,000 \mathrm{~km}^{2}$ and shed $2.4 \times 10^{6} \mathrm{t} / \mathrm{y}$ of sediments, which is slightly higher than estimated for the Paleocene period. This number is in agreement with results from presentday mountainous areas in the High Arctic compiled by Milliman and Syvitski (1992) (Fig. 14). The erosion estimates are found to be the highest of the entire Paleogene-Neogene period, up to $865 \mathrm{~m}$ with erosion rates of $0.039 \mathrm{~m} / \mathrm{k} . \mathrm{y}$. These high values represent major erosion of paleohighs that had been developed in the northwestern Barents Sea and Svalbard (e.g. HellandHansen, 2010). Fluvial-coastal and marine erosion might have governed the sediment transport and dispersal. Furthermore, basin modelling results from NE Greenland required a missing section of up to $400 \mathrm{~m}$ of sediments in the Eocene to explain the basin history (Stemmerik et al., 1998), which are largely in agreement with our erosion pattern.

\subsubsection{Oligocene and Neogene paleoenvironment and erosion of the source area}

The truncation of Oligocene-Neogene deposits eastwards towards the Hornsund Fault Zone indicate that the central and eastern segments may have been exposed at that time (Figs. 10c and d). The size of the depositional basins within the western segment were considerably larger than the preceding periods owing to the progressive seafloor opening to the west (Figs. 10c and d). The paleoenvironment to the east, over the central and eastern segments, is interpreted to have been a lowland area largely subjected to erosion while a deeper marine area prevailed in the western segment (Fig. 12c). The main sediment source area is interpreted to have been the Edgeøya platform, separated from the adjacent Kong Karl platform and the Bjarmeland Platform by a drainage divide (Fig. 12c). This drainage divide is inferred to have been caused by a reactivation of the Gardarbanken high during the Late Cretaceous (Anell et al., 2016), leaving a topographic high that may have acted as drainage divide during the OligoceneNeogene (Fig. 10c). From this, our estimated source area covers a total of 78,200 km².

The estimated average net erosion increases from $\sim 400 \mathrm{~m}$ in the Oligocene to $\sim 655 \mathrm{~m}$ in the Neogene. However, the erosion rate decreased slightly during this time. Erosion rates of 0.037 $\mathrm{m} / \mathrm{k}$.y and $0.032 \mathrm{~m} / \mathrm{k}$.y for the Oligocene and Neogene, respectively, were estimated. Sediment load and source area for the Oligocene and Neogene are analogous to those of modern systems from upland areas (relief of 500-1000 m) (Fig. 14), a setting previously also suggested by Rasmussen and Fjeldskaar (1996) for this area. 
The Oligocene was a period dominated by extension when Greenland moved NW relative to the Barents Sea shelf, resulting in a renewed seafloor spreading west of Svalbard (Talwani and Eldholm, 1977; Faleide et al., 2008). Thus, a substantial regional rift-flank uplift (Weissel and Karner, 1989) might have taken place during this period affecting the northern Atlantic realm (Green and Duddy, 2010; Praeg et al., 2005) possibly also including the study area.

In the Miocene, a significant opening of the Fram Strait (Engen et al., 2008; Kristoffersen, 1990) occurred, allowing along-slope ocean current circulation similar to the present. Moreover, to the east, a lowland area dominated by fluvial erosion has been suggested based on studies of the Upper Regional Unconformity (URU) morphology (Vorren et al., 1991).

In summary, paleoenvironmental reconstructions based on interpretation of seismic data, shallow drillings, and plate reconstruction were used to infer the drainage area for each period during the Paleogene-Neogene (Fig. 12). The average erosion and erosion rates are estimated and consistent with present-day observations. The sediment source area during the Paleocene is interpreted to have been the Stappen High and part of NE Greenland (Fig. 10a). The average erosion depth and erosion rates during this period are estimated to be $\sim 520 \mathrm{~m}$ and $0.052 \mathrm{~m} / \mathrm{k} . \mathrm{y}$, respectively (Table 2). In the Eocene, the sediment input was primarily coming from the northward extended Stappen High as well as part of NE Greenland (Fig. 10b). The estimated erosion in the Eocene is the highest during the entire Paleogene-Neogene period at $\sim 865 \mathrm{~m}$ and with the rates of $0.039 \mathrm{~m} / \mathrm{k} . \mathrm{y}$. During the Oligocene and Neogene, the Edgeøya platform acted as the main source area for sediments deposited along the northwestern Barents Sea margin (Fig. 10c). The average erosion depth is estimated to be $\sim 400$ and $\sim 655 \mathrm{~m}$ during the Oligocene and Neogene, respectively. The erosion rates is about $0.037 \mathrm{~m} / \mathrm{k}$.y for the Oligocene and 0.032 $\mathrm{m} / \mathrm{k} . \mathrm{y}$ for the Neogene period (Table 2).

\subsection{Erosion comparison in the western margin of the Barents Sea}

In this chapter, we compare our results with previous studies from the Norwegian margin for the same period of time and the younger glacial interval (Fig. 15). From our study, the total Paleogene-Neogene average net erosion for the northwestern Barents Sea margin is estimated to be $\sim 2440 \mathrm{~m}$. This number is higher compared to result from Hjelstuen et al. (1996) who suggested 1667 m of erosion. Although Hjelstuen et al., (1996) documented a similar total volume of $115,000 \mathrm{~km}^{3}$ for the Cenozoic pre-glacial deposits (their seismic unit G0), we consider this difference mainly due to dissimilarities in the size of the interpreted drainage area. In our study the size of the drainage areas varies for each period following the dynamic 
paleoenvironmental evolution due to the onset of sea-floor spreading in the NorwegianGreenland Sea (Fig. 12).

From the southwestern Barents Sea, the pre-glacial Cenozoic erosion is in the range of 5621360 (Fiedler and Faleide, 1996; Lasabuda et al., in review; Richardsen et al., 1993), which are lower than numbers reported in the NW Barents Sea (Fig. 15). For the total pre-glacial erosion rate, our estimate shows a value of $0.38 \mathrm{~m} / \mathrm{k} . \mathrm{y}$. Our pre-glacial erosion rate is higher compared with the southwestern Barents Sea, where pre-glacial erosion rates of $0.012-0.021 \mathrm{~m} / \mathrm{k} . \mathrm{y}$ have been reported (Fiedler and Faleide, 1996; Lasabuda et al., in review). We also link these differences to variation in tectonic development along the western margin of the Barents Sea continental margin in the early-middle Cenozoic (e.g. Faleide et al. 1993). This north-south trending margin was dominated by shear transtension in the Senja Fracture Zone, extension in the Vestbakken volcanic province, and compression-transpression on Spitsbergen leading to the fold-thrust belt development (Bergh et al., 1997; Faleide et al., 2008). This overall setting gave way to a higher erosion rate of a source area that was probably dominated by a higher relief (larger area of exposure) towards the north (e.g. Rasmussen and Fjeldskaar, 1996). Moreover, a compilation of the total Cenozoic net erosion (Henriksen et al. 2011) also supports the northern increasing trend along this margin.

The late Cenozoic glacial erosion for the northwestern Barents Sea area is estimated to be 1681 m (Hjelstuen et al., 1996). This number implies that less than half of the total average Cenozoic erosion in this area is of glacial origin. By adding this number to our results for the Cenozoic pre-glacial erosion $(2439 \mathrm{~m})$, the total average net Cenozoic erosion for this area is about $\sim 4100$ $\mathrm{m}$. This total estimate is in agreement with the total net denudation of the Stappen High that shows a missing overburden in the order of 3000-4200 m suggested by several studies using various techniques (Henriksen et al., 2011; Ritter et al., 1996; Wood et al., 1989). These numbers confirm that the Stappen High experienced severe erosion probably also affecting the Loppa High, shedding sediments to the adjacent basins (e.g. Wood et al., 1989). This can be explained through a longer exposure of the Stappen High (Worsley, 2008), as well as tectonic compression affecting this area since the early Cenozoic (Sættem et al., 1994) amplified by riftflank uplift evident from volcanism (e.g. Eldholm et al., 2002).

In addition, the glacial erosion rates from the northwestern Barents Sea have been documented to be $0.63 \mathrm{~m} / \mathrm{k}$.y (Hjelstuen et al., 1996). This number shows that, at this location, glacial erosion rates are one order of magnitude higher compared to the pre-glacial erosion rates estimated in this study $(0.038 \mathrm{~m} / \mathrm{k} . \mathrm{y})$. A similar trend of increasing erosion rates from areas that have 
experienced periods of pre-glacial and glacial erosion are seen from other mass-balance studies including Isfjorden (Svalbard), the southwestern Barents Sea, and mid-Norway. Here the glacial erosion rates are reported to be $0.2 \mathrm{~m} / \mathrm{k} . \mathrm{y} .0 .4 \mathrm{~m} / \mathrm{k} . \mathrm{y}$, and $0.19 \mathrm{~m} / \mathrm{k} . \mathrm{y}$, respectively (Dowdeswell et al., 2010; Elverhøi et al., 1998; Laberg et al., 2012). These results testify that the ice-sheet appears to have been a very effective agent in sediment erosion and delivery during the intensified northern hemisphere glaciations (e.g. Laberg et al., 2010; 2012; Vorren et al., 2011).

In contrast to glacial erosion, that largely was controlled by bedrock composition, paleoclimate, as well as glacial dynamics (Laberg et al., 2012); we suggest that the pre-glacial erosion was strongly linked with the tectonic development of the study area. We consider the paleogeography caused by the tectonics as a dominant controlling factor in defining drainage area in influencing the sediment transport and pathways. Therefore, the relative uplift and subsidence of structural elements and the associated geomorphological dynamics are essential in the pre-glacial mass-balance approach (e.g. Sømme et al., 2009). Furthermore, bedrock composition may determine the erodibility of substrate in the source area affecting the erosional volume.

\section{Conclusions}

The main findings of this study can be summarized as follows:

- The Cenozoic tectonostratigraphy of the northwestern Barents Sea continental margin is investigated, showing a series of complex structures associated to strike-slip and normal faulting. South of $75^{\circ} 50 \mathrm{~N}$, the margin is characterized by predominatly normal faults with negative flower structures, indicating a transtensional setting in the early Cenozoic. Within the southern part of the central segment, the margin experienced predominantly an extensional setting as shown by listric normal faults, rollover structures, and a series of horsts and grabens. The evolution of the margin is strongly linked to the plate tectonic development between Greenland and the Barents Sea shelf.

- The total Paleogene-Neogene isopach map shows a general thinning northwards trend with a total depositional volume of $115,400 \mathrm{~km}^{3}$ covering an area of up to $53,200 \mathrm{~km}^{2}$ of the northwestern margin of Barents Sea. The estimated average sedimentation rate of $0.034 \mathrm{~m} / \mathrm{k} . \mathrm{y}$. for the Cenozoic pre-glacial period is one order of magnitude lower than for the younger glacial period. 
- The area from the southern tip of Svalbard to the Stappen High, the Edgeøya platform, and part of NE Greenland acted as the most likely sediment source areas for the Paleogene-Neogene sediments. The estimated erosion volume was $115,400 \mathrm{~km}^{3}$ derived from an area of $78,200 \mathrm{~km}^{2}$.

- A general increasing trend of pre-glacial erosion northwards along the western margin of the Barents Sea shelf can be inferred. The comparison with modern systems shows that our sediment discharge and size of drainage area are reasonable estimates. The mass-balance method has been used and shows that $2440 \mathrm{~m}$ has been eroded from the source area with average erosion rates of $0.038 \mathrm{~m} / \mathrm{k}$.y. This may represent a minimum value, as the deposited sediment budget may have been larger due to limited seismic coverage as well as its later erosion in the glacial period.

- The pre-glacial erosion was strongly linked with the tectonic development of the study area. We consider the paleogeography controlled by the tectonic setting as a dominant factor in defining the drainage area and to have influenced the sediment transport and pathways.

\section{Acknowledgements}

This research is funded by Research Centre for Arctic Petroleum Exploration (ARCEx) partners and the Research Council of Norway (grant number 228107). We are grateful to the Russian Joint Stock Company 'Russian Marine Arctic Geological Expedition' (MAGE) for providing the seismic data. Permission has been granted from TGS/Spectrum to publish part of the seismic profile in Figure 4. Schlumberger is acknowledged for the Petrel software under an educational license agreement to Department of Geosciences, UiT - The Arctic University of Norway. Tom Birchall and Laura Swinkels are thanked for proofreading the text. We are thankful to Steffen Bergh for discussions, and Jan Inge Faleide and Winfried Dallmann for the valuable comments on the manuscript. We also thank Editor-inChief Irina Artemieva and Editor Morten Smelror for helpful suggestions. Detailed constructive reviews by Tor Eidvin, Fridtjof Riis, and Tim Redfield are highly acknowledged. 


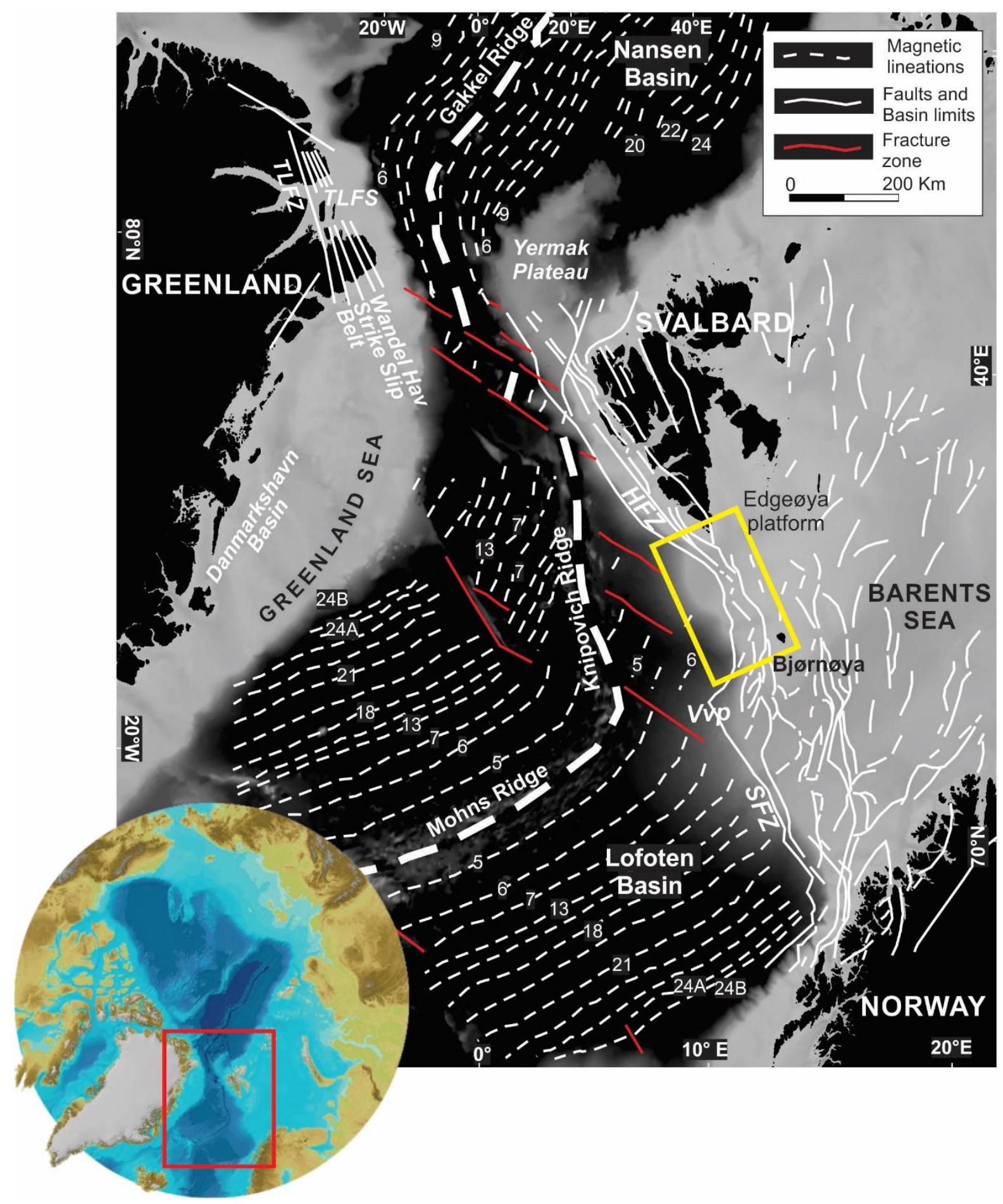

Fig. 1. Regional geology of the western margin of the Barents Sea. The study area is shown by yellow rectangle. The bathymetry is derived from International Bathymetric Chart of the Arctic Ocean (IBCAO) v. 3.0 (Jakobsson et al., 2012). Magnetic lineations are taken from Mosar et al. (2002) and Jokat et al. (2016). The structural configuration is modified from Faleide et al. (2015). TLFZ: Trolle Land Fault Zone, TLFS: Trolle Land Fault System, HFZ: Hornsund Fault Zone, Vvp: Vestbakken Volcanic Province, SFZ: Senja Fracture Zone. 

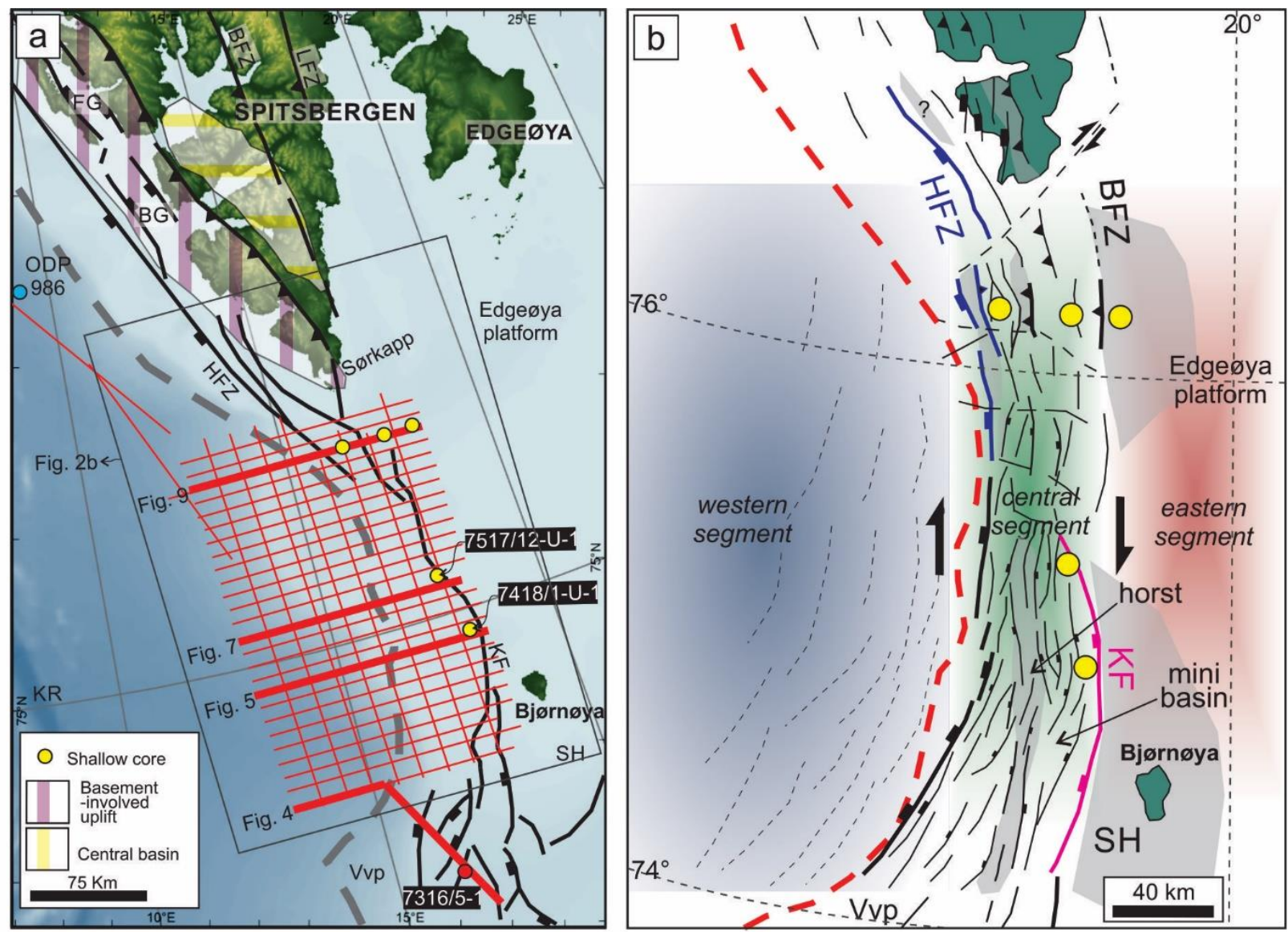

Fig. 2. (a) The 2D seismic lines and exploration well data used in this study. The bold red lines represent the location of the selected geoseismic profiles (Figures $4-9$ ). The shallow cores and ODP Site 986 location are from Grogan et al. (1999) and Jansen et al. (1996), respectively. Structural configuration and continent-oceanic boundary (COB) (dashed line) are taken from Faleide et al. (2015). The bathymetry is modified from IBCAO v. 3.0 (Jakobsson et al., 2012). BG: Bellsund Graben, BFZ: Billefjorden Fault Zone, FG: Forlandsundet Graben, HFZ: Hornsund Fault Zone, KR: Knipovich Ridge, KF: Knølegga Fault, LFZ: Lompfjorden Fault Zone, SH: Stappen High, Vvp: Vestbakken volcanic province. (b) Stuctural map for the northwestern Barents Sea margin and area subdivision into three segments. Fault configuration on Svalbard and its surroundings are based on Bergh and Grogan (2003). Grey shaded areas are illustrating the highs/ridges. HFZ and KF are shown in blue and purple color, respectively. 


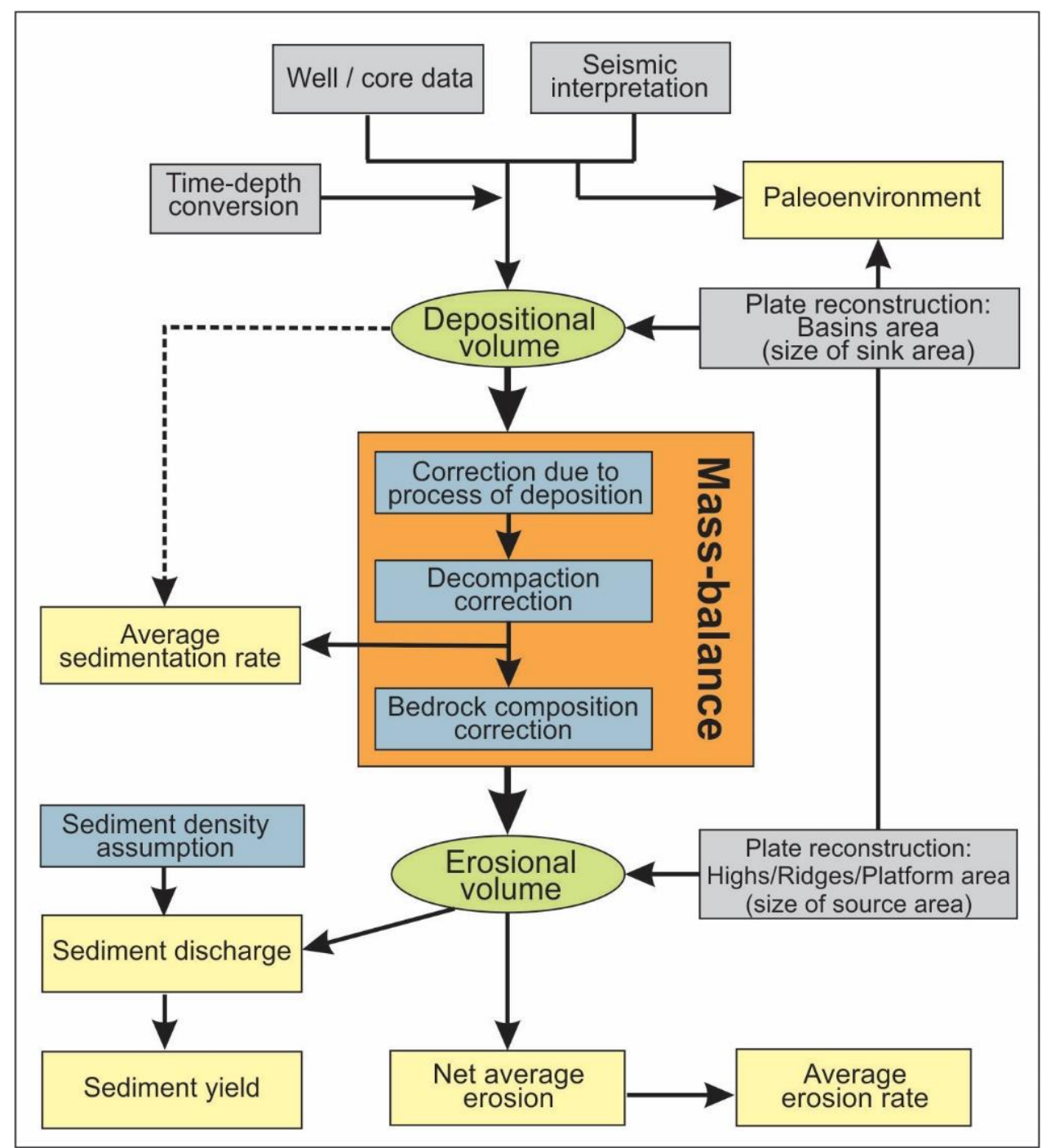

Fig. 3. Flowchart outlining the mass-balance method used in this study. The dashed line shows that the average sedimentation rate can also be calculated before the corrections are applied, depending on the aim of the study. 

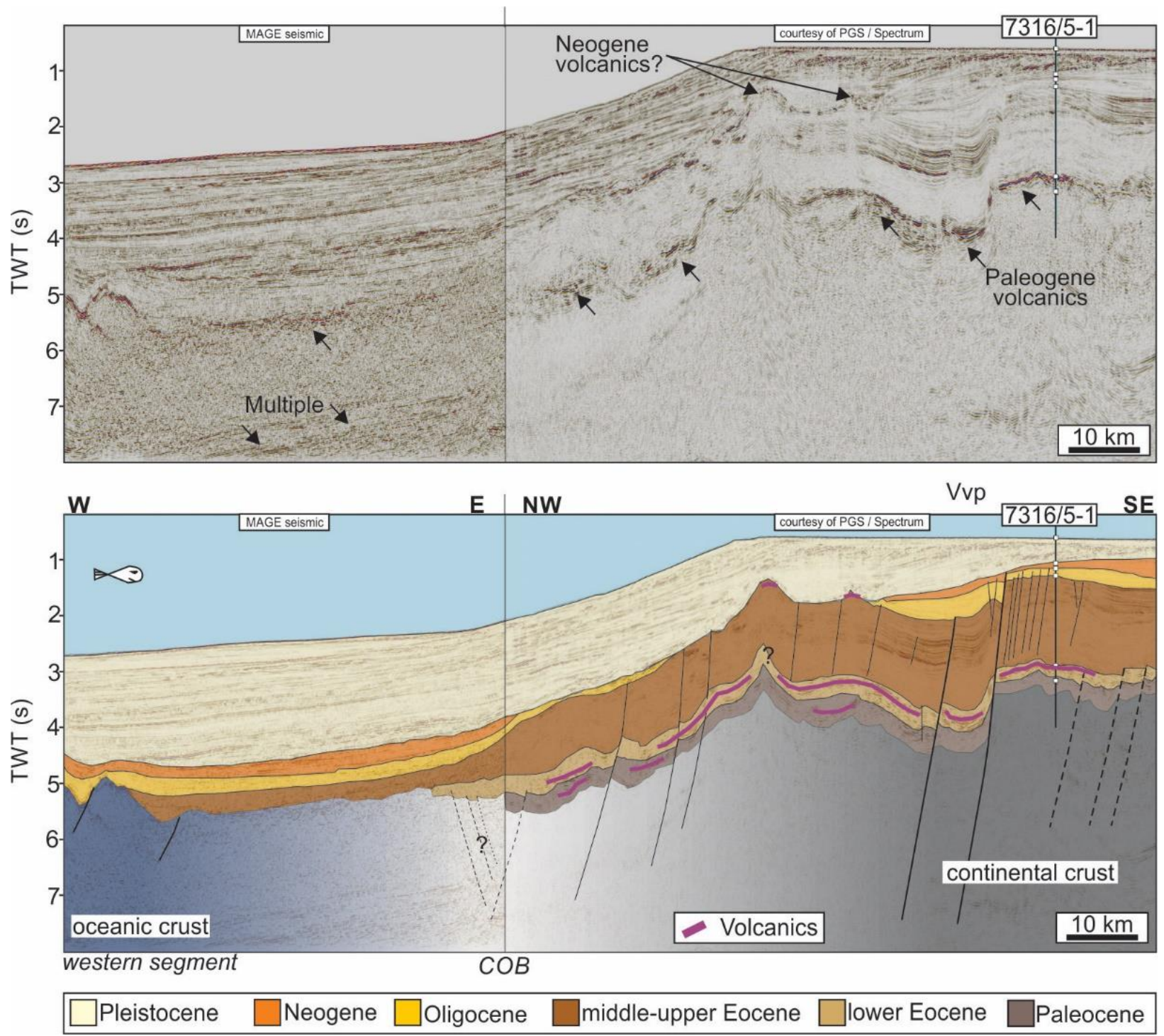

Fig. 4. Uninterpreted and interpreted seismic section showing the stratigraphy of the study area tied to well tops from NPD for well 7316/5-1. The lower Eocene strata is abundant with volcanics. The Oligocene-Neogene strata are seen terminating underneath the Pleistocene layer. $\mathrm{COB}=$ continentalocean boundary. For seismic profile's location, see Fig. 2a. 

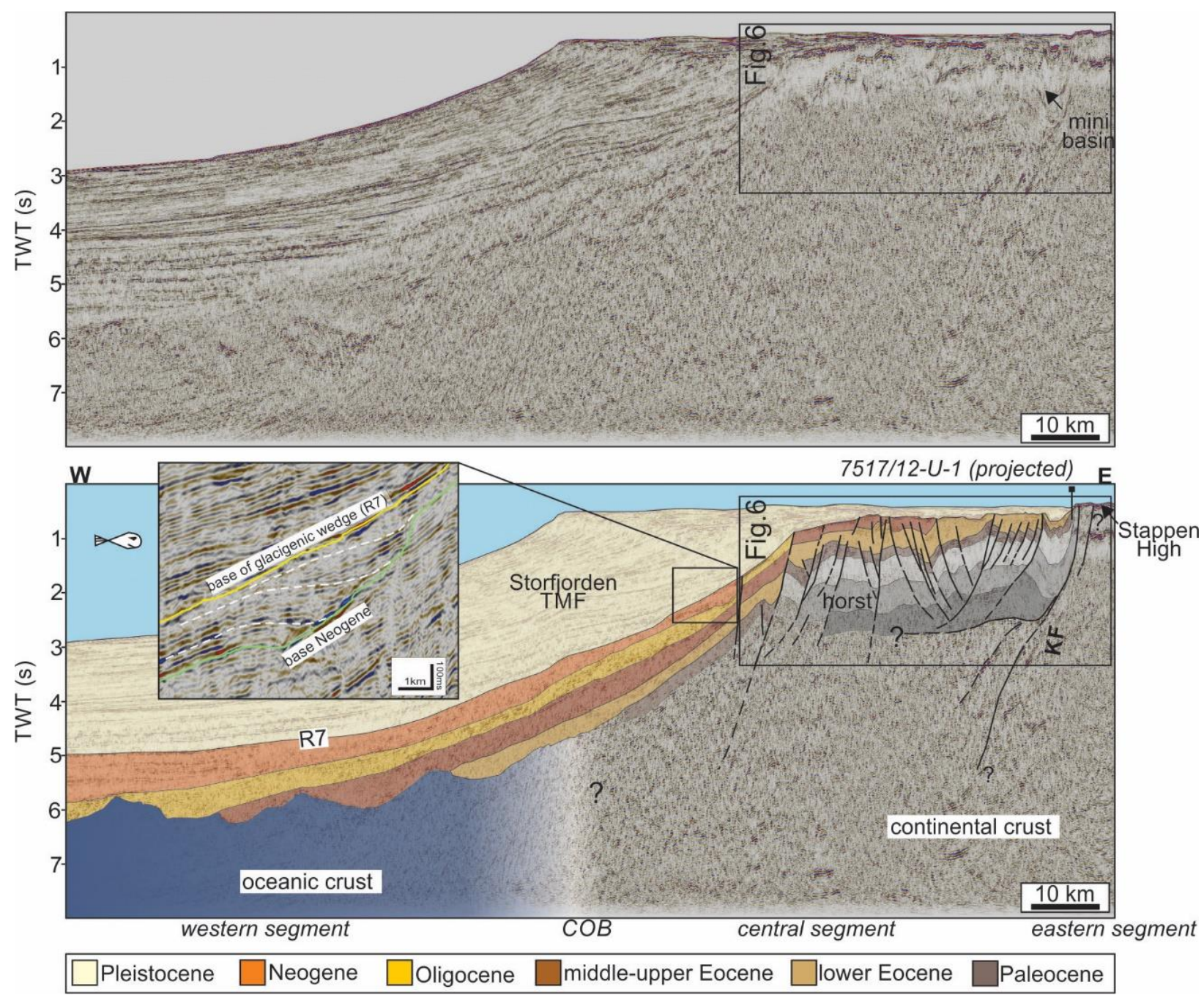

Fig. 5. Uninterpreted and interpreted seismic section showing the northward thinning of Paleogene strata at the central segment compared to the area of Figure 4. The seismic units are tied to the shallow core (projected) as documented by Eikelmann (2017). The Oligocene-Neogene strata thickens towards the west. Note that the Paleogene-Neogene strata are seen onlapping the oceanic crust indicating the progressive seafloor spreading. Inset: zoomed-in seismic section showing Miocene contourites development within the continental slope as a result of oceanic circulation between the North Atlantic and the Arctic Ocean. Location of the seismic profile is indicated in Fig. 2a. 


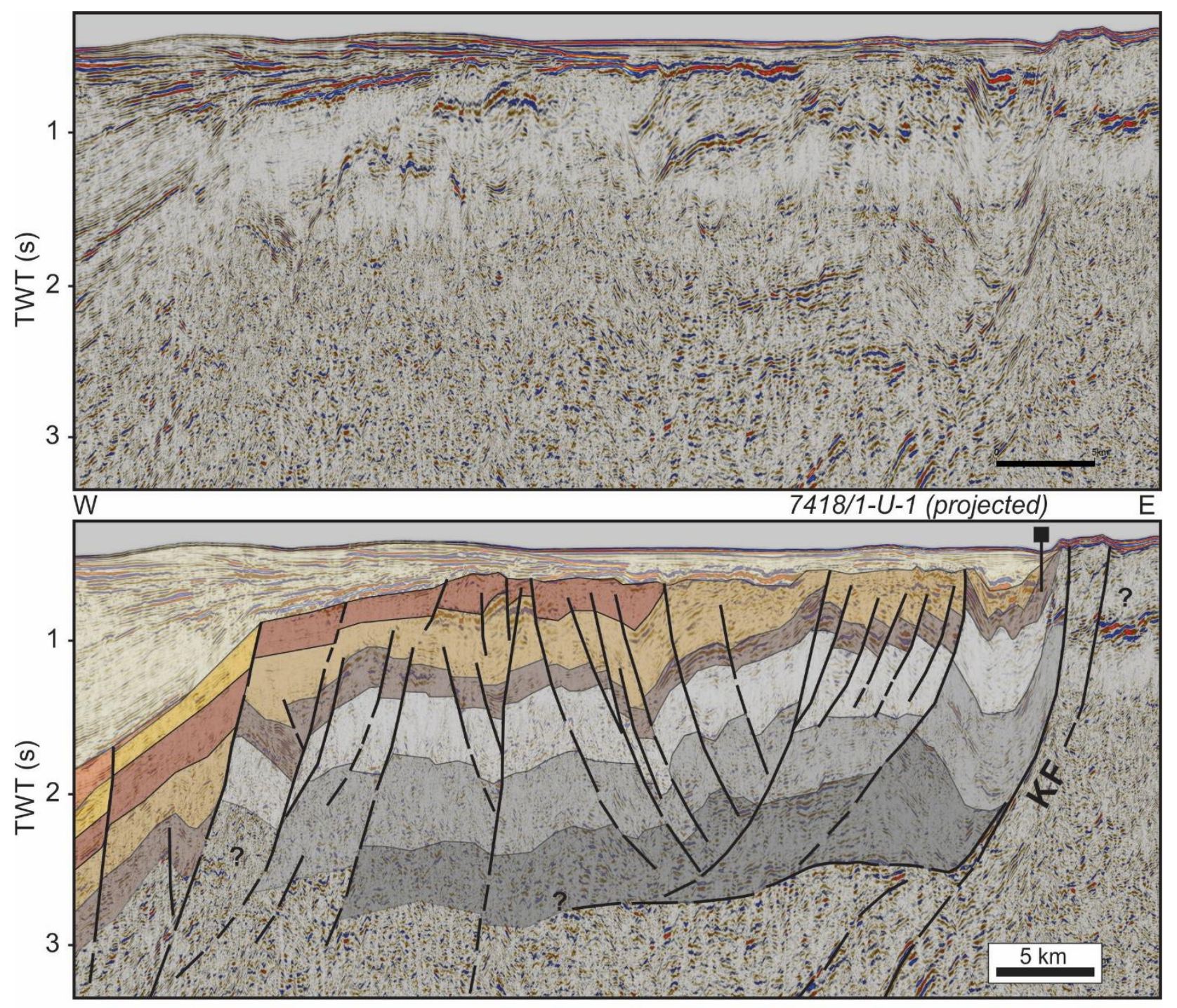

$\square$ Pleistocene $\square$ Neogene $\square$ Oligocene $\square$ middle-upper Eocene $\square$ lower Eocene $\square$ Paleocene

Fig. 6. Zoomed in profile from Figure 5 showing a series of normal faults and rollover structures. A potential detachment surface accommodates the growth of the listric normal faults. The faulting also formed horst and graben structures. The structural style suggests an extensional setting for this area. 

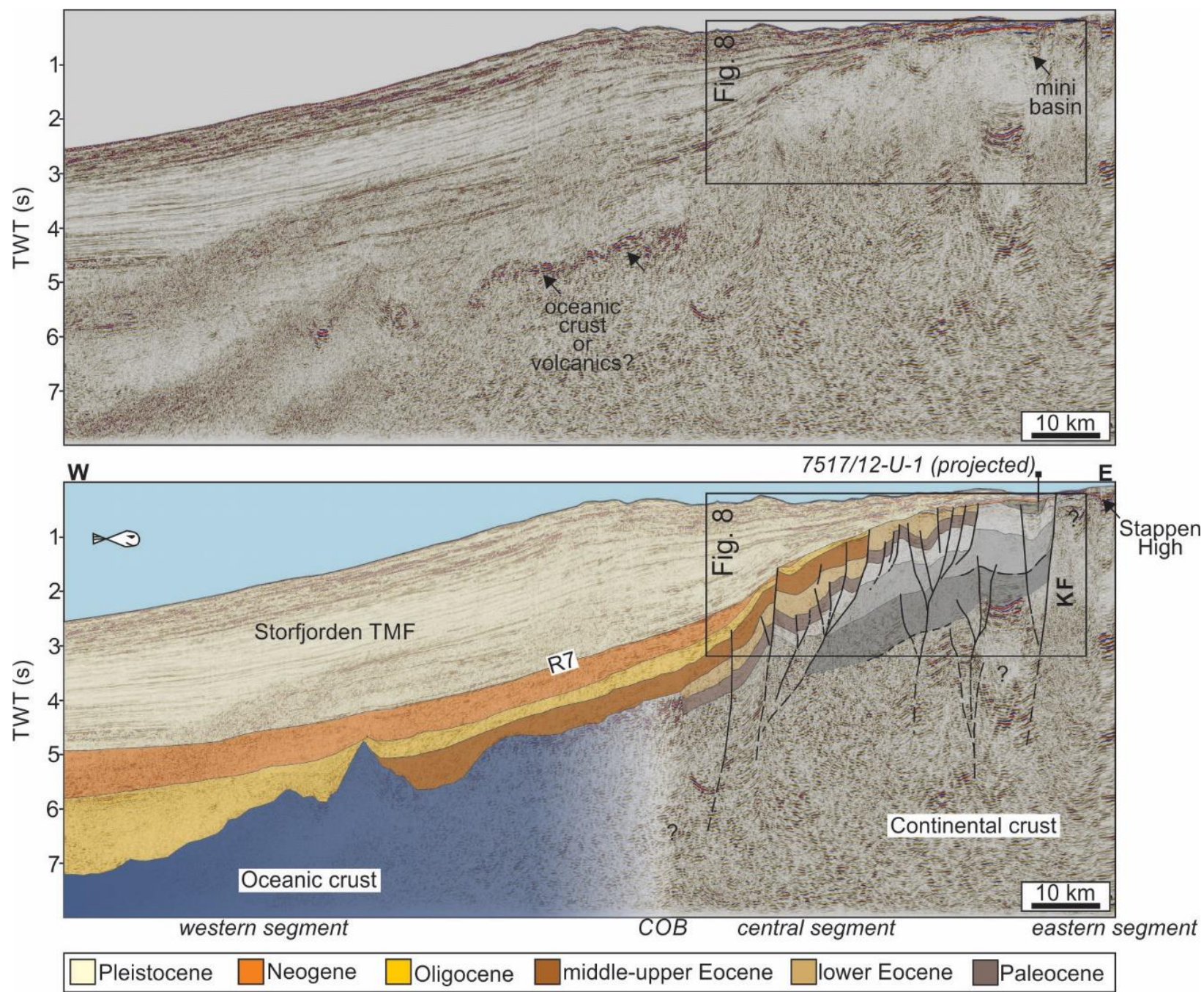

Fig. 7. Uninterpreted and interpreted seismic section illustrating the negative flower structures. The shallow core (projected) shows a marine deposit at the upper Paleocene strata (Eikelmann, 2017). The seismic section displays a strong amplitude contrast of oceanic and continental crust. Location of the seismic profile is shown in Fig. 2a. 

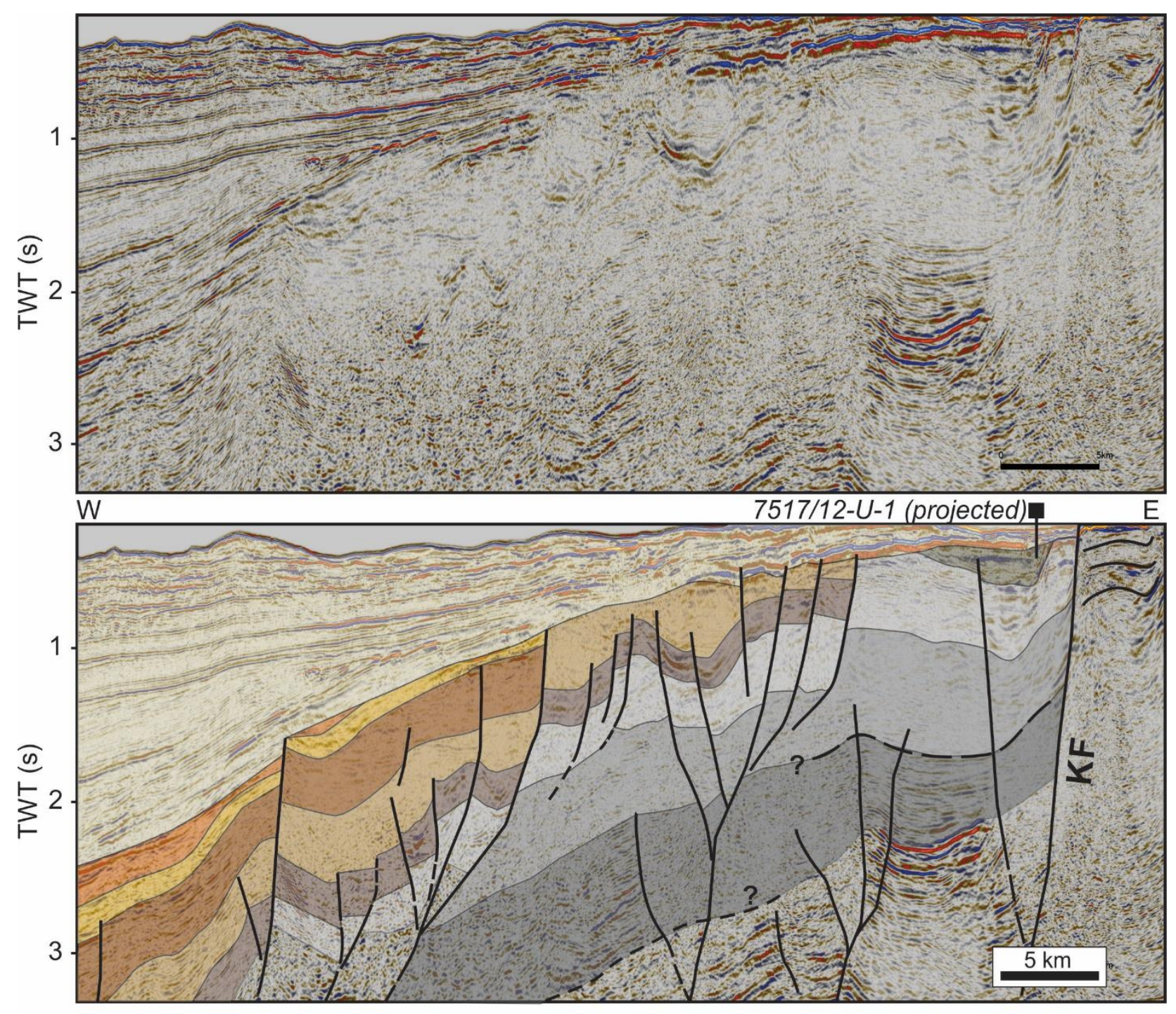

$\square$ Pleistocene $\square$ Neogene $\square$ Oligocene $\square$ middle-upper Eocene $\square$ lower Eocene $\square$ Paleocene

Fig. 8. Zoomed in profile from Figure 7 showing a set of normal faults, which formed in negative flower structures. The flower structures suggest that influence of transtension appears to be more pronounce to the north. 


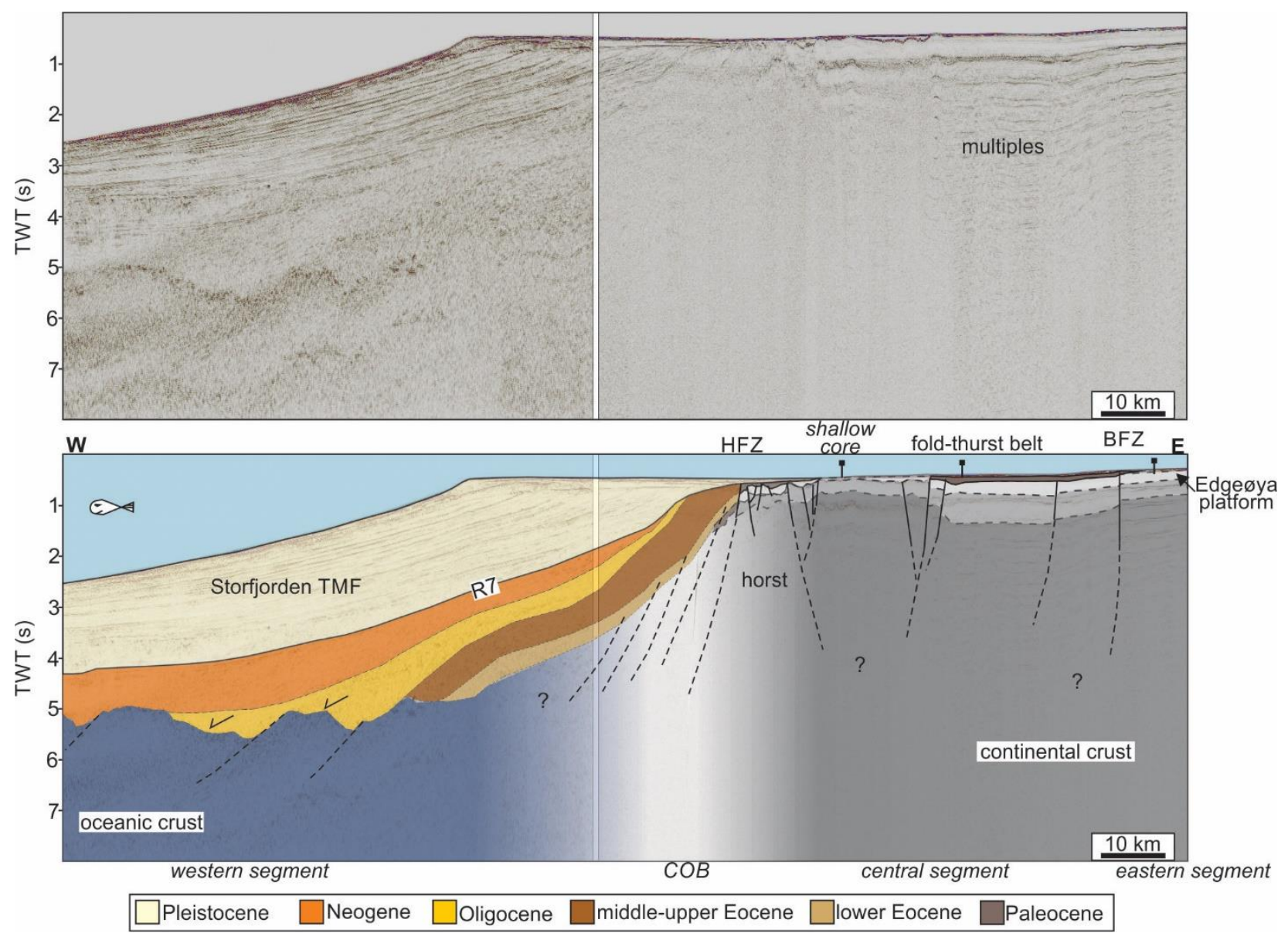

Fig. 9. Uninterpreted seismic section (with strong multiples towards the east) and interpreted seismic section illustrating the southward continuation of the onshore structural style on Svalbard. The offshore part of the WSFTB interpretation is consistent with Bergh and Grogan (2003). The Billefjorden Fault Zone marks the limit to the Edgeøya platform. This section has been correlated to the shallow core data from Grogan et al. (1999) documenting Cretaceous, Paleocene, Cretaceous subcrops for those 3 cores, respectively from the east. The seismic profile's location is indicated in Fig. 2a. 

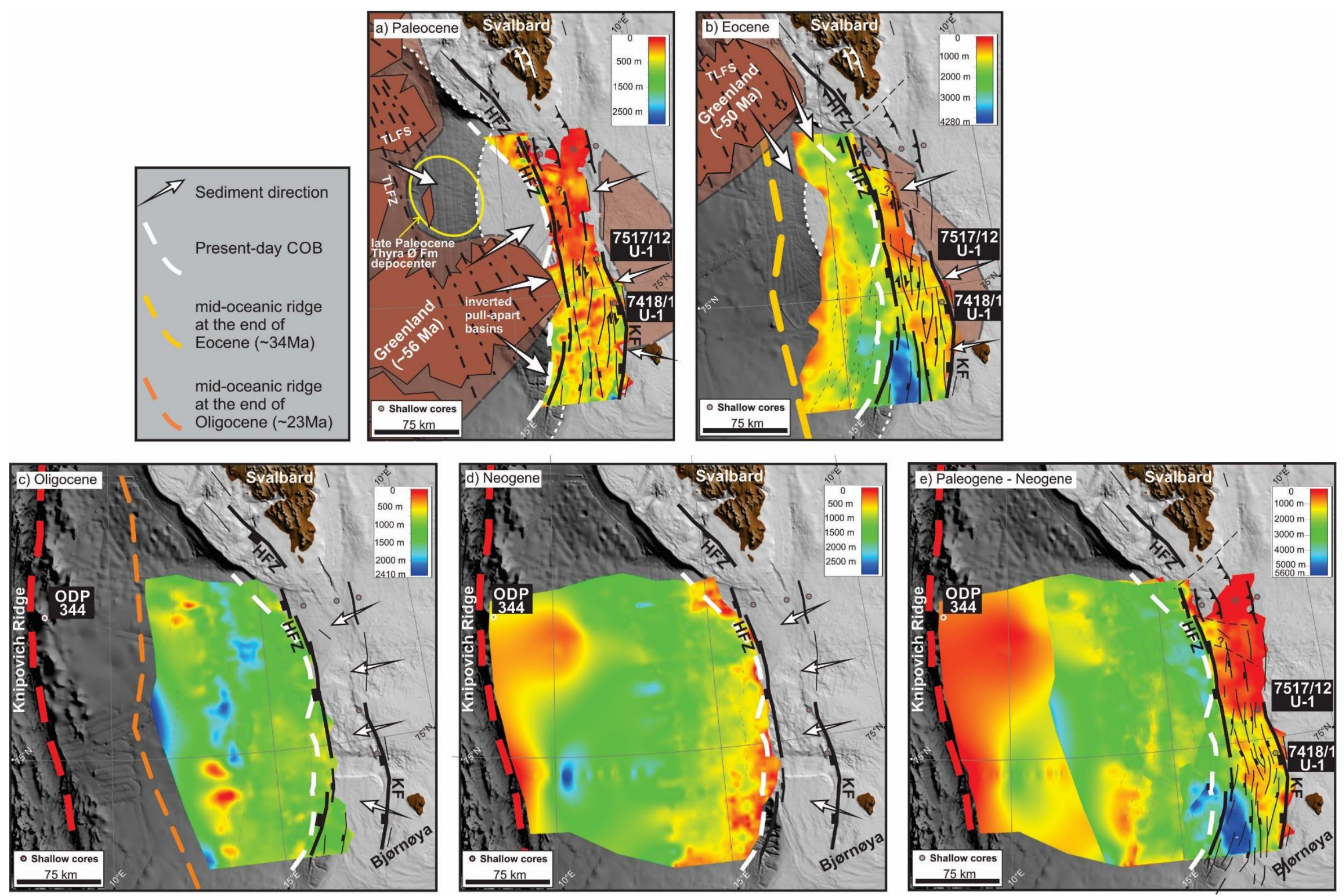
Fig. 10. (previous figure) Isopach maps illustrating the thickness variation for the periods addressed in this study. (a) Paleocene isopach map with respect to paleogeography of Greenland at $~ 56$ Ma. The inverted pull-apart basins, TLFZ, and TLFS on Greenland are adapted from Håkansson and Pedersen (2001; 2015). The late Paleocene Thyra $\emptyset$ Formation depocenter is according to Lyck and Stemmerik (2000) and Døssing et al. (2010). (b) Eocene isopach map relative to Greenland position at $~ 50 \mathrm{Ma}$. (c) Oligocene isopach map with source area only from the Barents Sea shelf (Edgeøya platform), as Greenland's position at 33 Ma was not favorable to supply sediment to the study area. (d) Neogene isopach map includes Pliocene sediments reaching the location of ODP 344 . (e) Paleogene-Neogene total isopach map for the northwestern Barents Sea. Note the overall thinning of sediments towards the north. Fault mapping in the Barents Sea area is adapted from Bergh and Grogan (2003) and this study. Greenland and paleo-mid oceanic ridge approximate positions are based on plate reconstruction with fixed western Svalbard position from GPlates v. 2.0 (Matthews, et al., 2016; Muller et al., 2016). COB is taken from Faleide et al. (2015). The bathymetry is modified from IBCAO v. 3.0 (Jakobsson et al., 2012) with projection ED50-UTM33N. TLFZ: Trolle Land Fault Zone, TLFS: Trolle Land Fault System. 


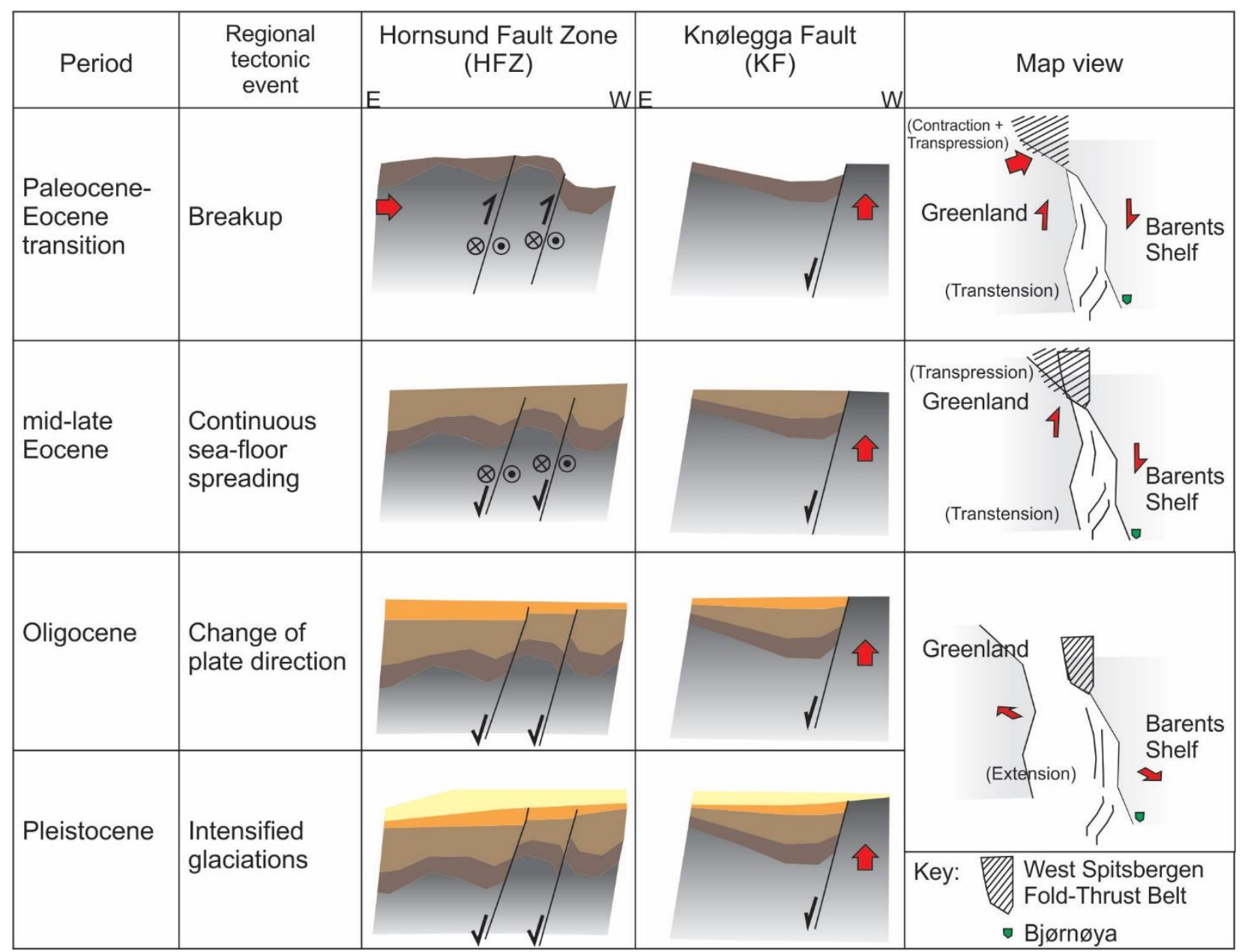

Fig. 11. Schematic diagram summarizing the development of Hornsund Fault Zone and Knølegga Fault during the Cenozoic time. The tectonic configuration with respect to relative plate movement is also shown in map view. 

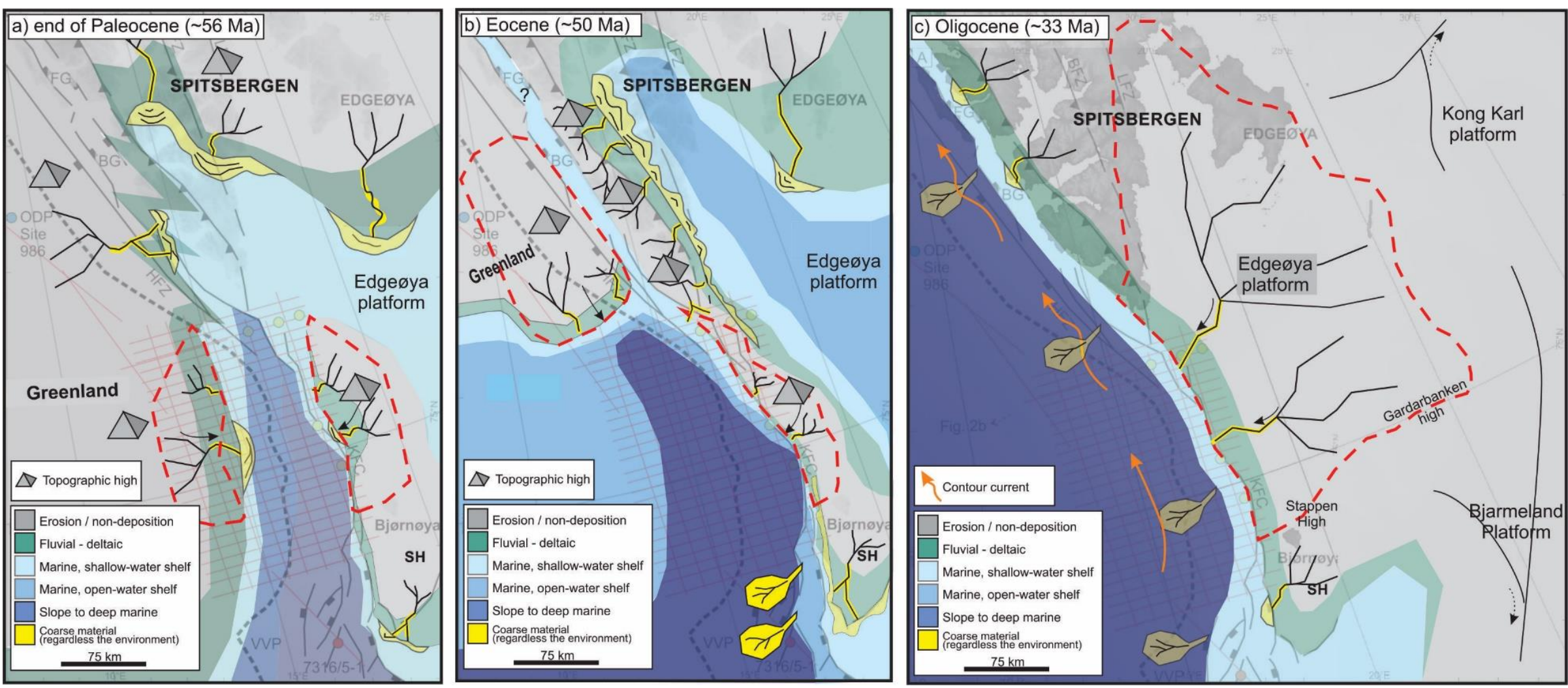

Fig. 12. Paleoenvironmental reconstruction for the key periods in early-middle Cenozoic at the northwestern Barents Sea shelf, (a) end of Paleocene ( $\sim 56 \mathrm{Ma})$, (b) Eocene ( $\sim 50 \mathrm{Ma})$, and (c) Oligocene ( 33Ma). The red dashed lines are the delineation of the inferred source area. Base map is derived from Faleide et al. (2008). These maps are a compilation from various resources including, Vorren et al. (1991), Smelror et al. (2009), Helland-Hansen (2010), Dallmann (2015), Faleide et al. (2015), Guarnieri (2015), Håkansson and Pedersen (2015), Piepjohn et al. (2016), and Eikelmann (2017). The plate reconstruction is based on GPlates v. 2.0 (Matthews et al., 2016; Muller et al., 2016). The location of the seismic data and shallow cores are indicated. See text for discussion. 


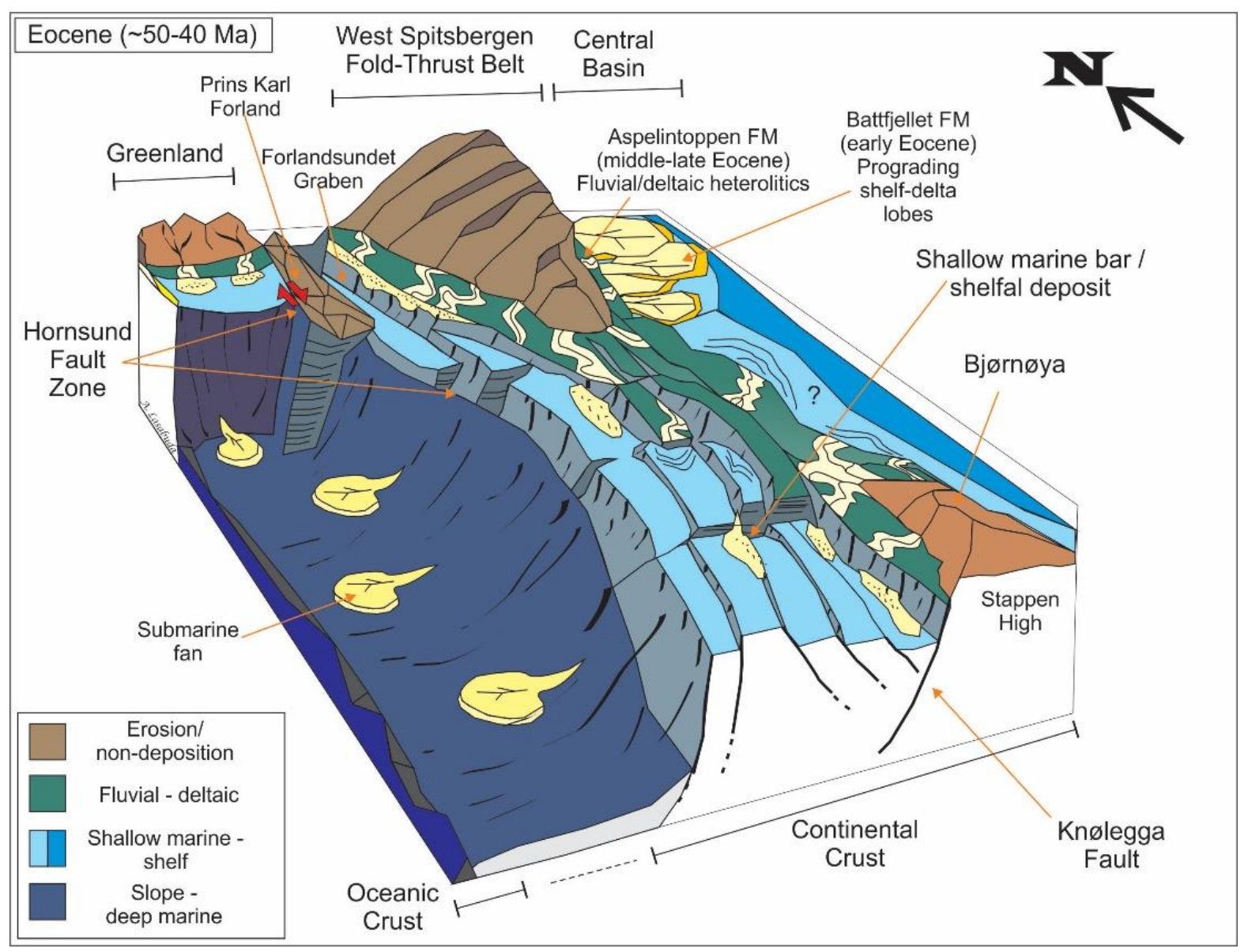

Fig. 13. Conceptual 3D figure for the northwestern Barents Sea in the Eocene period showing the main pattern of sedimentation and interpreted source areas. The paleogeography during the Eocene indicates that Greenland transpressed Svalbard through the northern part of the Hornsund Fault Zone (Steel et al., 1985; Bergh et al., 1997). This event resulted in the mountainous WSFTB and the deposition of the Battfjellet FM and Aspelintoppen FM in the Central Basin on Svalbard (Helland Hansen et al., 2010). To the south, the Stappen High acted as prominent sediment source delivering sediments to the adjacent basins. 


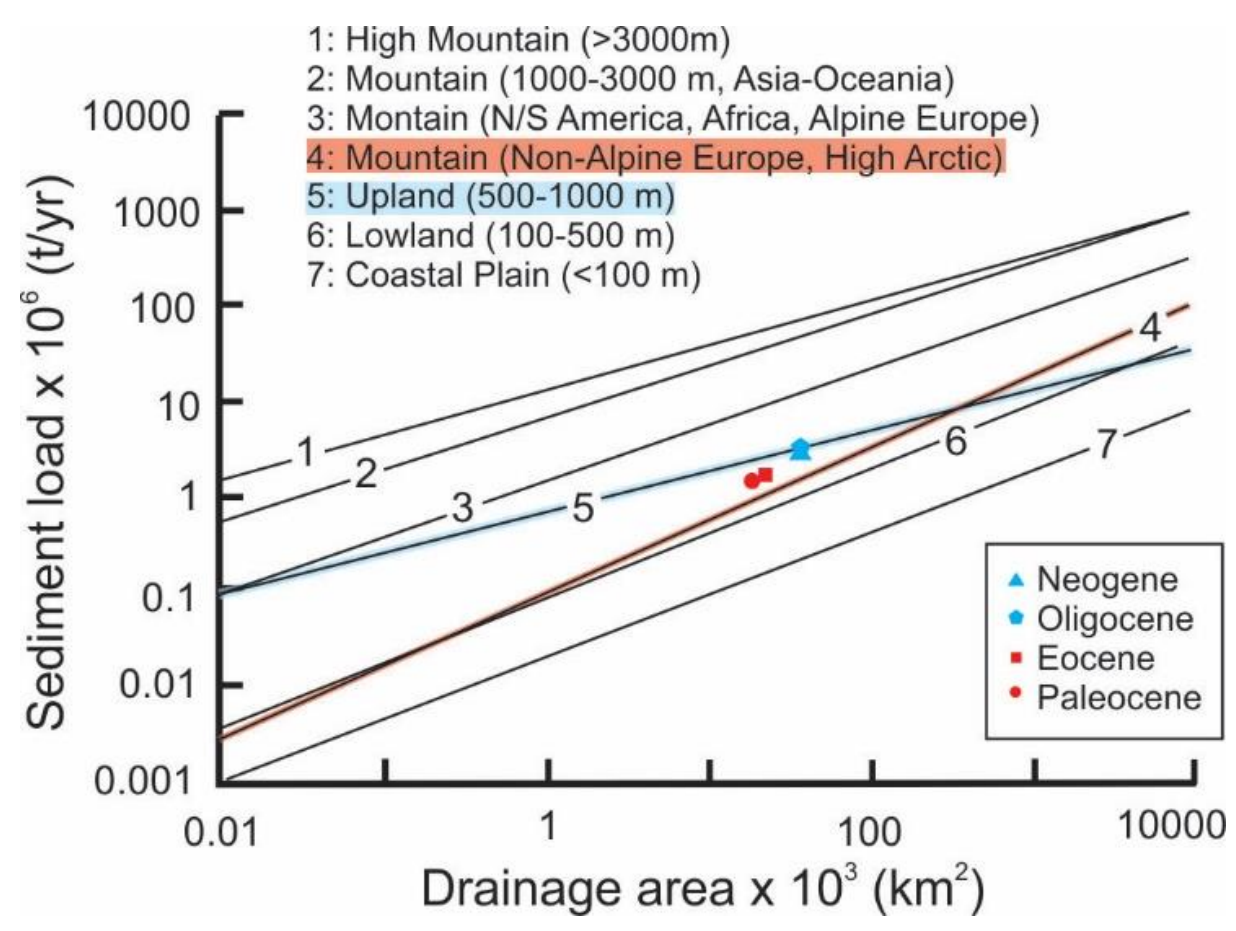

Fig. 14. Cenozoic average sediment load for each periods are plotted against size of drainage area using the complied diagram from Milliman and Syvitski (1992). The Paleocene and Eocene estimates show a close correlation with present-day fluvial system in mountainous High Arctic. Our Oligocene and Neogene estimates corresponds to present-day fluvial system in Upland areas. This plot illustrates that our size of drainage area and the corresponding estimates are comparable with present-day systems.

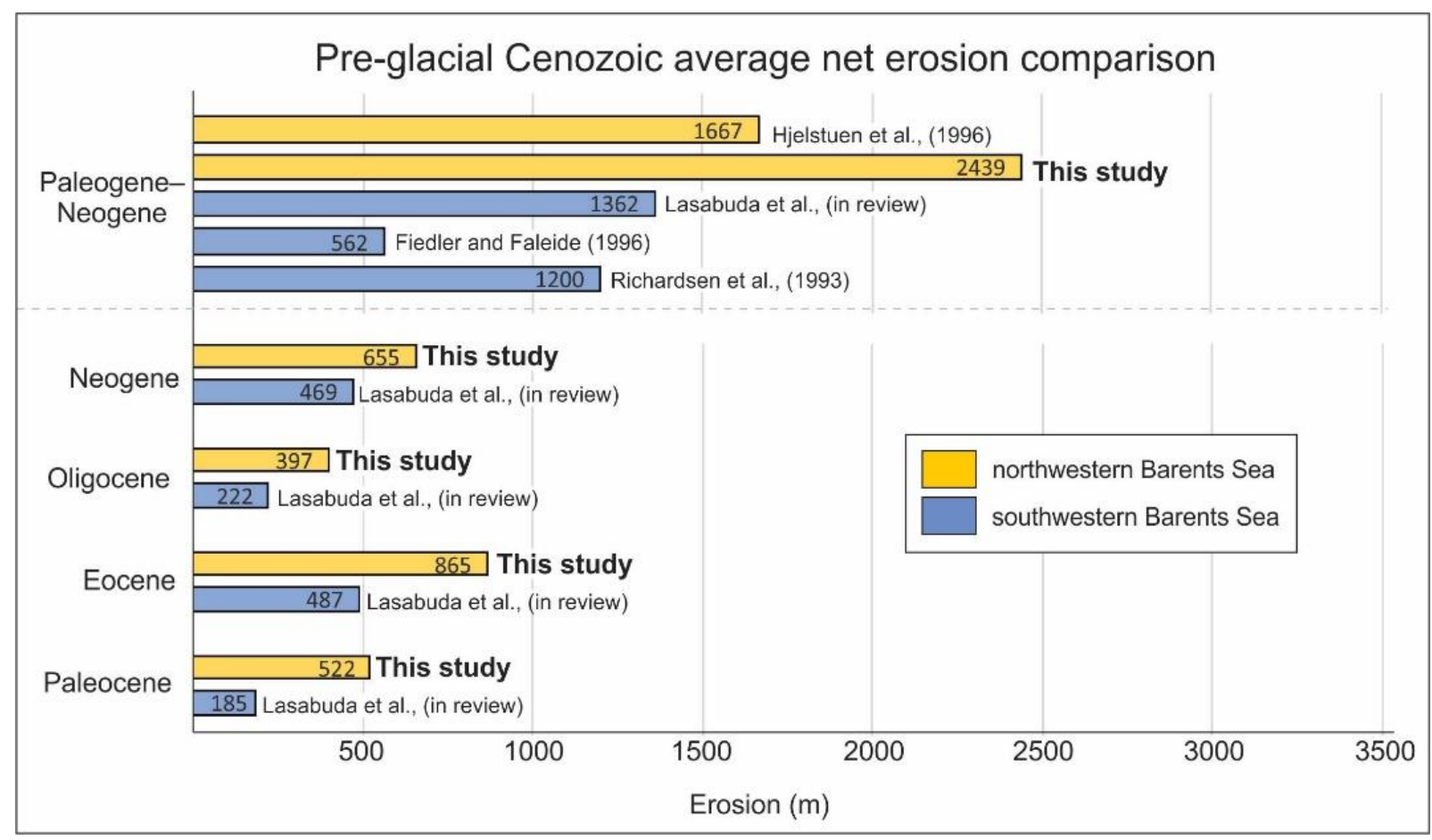

Fig. 15. Comparison of Cenozoic average net erosion in the western margin of the Barents Sea. Our Paleogene-Neogene (pre-glacial) erosion estimates are higher than for similar periods in the southwestern Barents Sea. This indicates that the northwestern Barents Sea was more prone to erosion in agreement with our paleoenvironmental reconstruction. Note that the areas subjected to erosion were different in each study. 